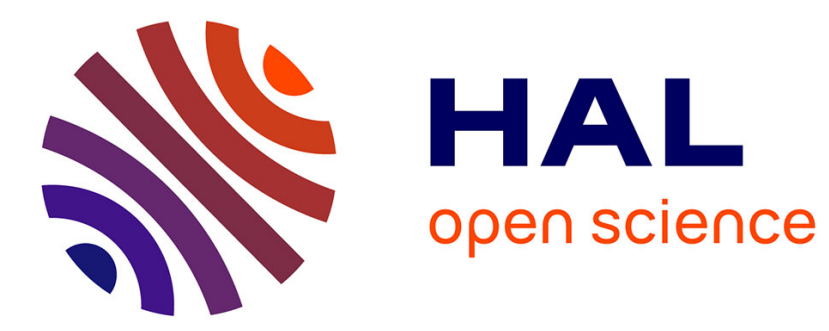

\title{
Analysis and Mapping of an Updated Terrestrial Heat Flow Data Set \\ F. Lucazeau
}

\section{To cite this version:}

F. Lucazeau. Analysis and Mapping of an Updated Terrestrial Heat Flow Data Set. Geochemistry, Geophysics, Geosystems, 2019, 20 (8), pp.4001-4024. 10.1029/2019gc008389 . hal-02325104

\section{HAL Id: hal-02325104 \\ https://hal.science/hal-02325104}

Submitted on 22 Oct 2019

HAL is a multi-disciplinary open access archive for the deposit and dissemination of scientific research documents, whether they are published or not. The documents may come from teaching and research institutions in France or abroad, or from public or private research centers.
L'archive ouverte pluridisciplinaire HAL, est destinée au dépôt et à la diffusion de documents scientifiques de niveau recherche, publiés ou non, émanant des établissements d'enseignement et de recherche français ou étrangers, des laboratoires publics ou privés. 


\title{
Analysis and mapping of an updated terrestrial heat flow dataset
}

\author{
F. Lucazeau ${ }^{1}$ \\ ${ }^{1}$ Université de Paris, Institut de physique du globe de Paris, CNRS, IGN, F-75005 Paris, France
}

\section{Key Points:}

- This compilation of terrestrial heat flow includes almost 70,000 measurements

- Global heat loss based on measurements only ranges between 40-42 TW, close to previous estimates using conductive cooling models (45-47 TW)

- A generalized similarity method is used to map global variations of surface heat flow on a $0.5^{\circ} \times 0.5^{\circ}$ grid. The best prediction is obtained for 14 observables.

Corresponding author: F. Lucazeau, lucazeau@ipgp.fr 


\begin{abstract}
The number of heat flow measurements at the Earth surface has significantly increased since the last global analysis (Pollack et al., 1993), and the most recent of them provide insights into key locations. This paper presents a new compilation, which includes approximately 70,000 measurements. Continental heat flow $\left(67 \mathrm{mWm}^{-2}\right)$ does not change significantly, but the differences are more important for oceanic heat flow. The divergence with conductive cooling models is reduced significantly for young ages of the seafloor, since the most recent measurements $\left(92 \mathrm{mWm}^{-2}\right)$ are significantly higher on average than the older ones $\left(79 \mathrm{mWm}^{-2}\right)$. This is related to a better quality and a better sampling of measurements in regions affected by hydrothermal circulation. The total Earth heat loss derived from these most recent measurements is estimated to $\sim 40-42 \mathrm{TW}$ and represents only 3-5 TW less than with a conductive cooling model $(\sim 45-47 \mathrm{TW})$. Hydrothermal heat loss in the oceanic domain is estimated with a new method based on the ruggedness of the seafloor, and represents $\sim 1.5 \mathrm{TW}$ more than previous estimates. The heat flow variability on continents is so large that defining a trend with stratigraphic or tectono-thermal age is difficult and makes extrapolation from age a poor predictor. On the other hand, additional geological and geophysical information can be combined with age for better predictions. A generalized similarity method was used here to predict heat flow on a global $0.5^{\circ} \times 0.5^{\circ}$ grid. The agreement with local measurements is generally good and increases with the number and quality of proxies.
\end{abstract}

\title{
1 Introduction
}

Surface heat flow, which represents the energy flux through a unit surface, is a fundamental expression of the Earth dynamics. The measurement technique, based on the Fourier's law, simply relates the surface heat flow to the product of the vertical thermal gradient and thermal conductivity. However, measuring thermal gradient is not practically easy and the measurement itself is complicated by several types of surface perturbations (climatic changes, topography, water circulation, erosion or sedimentation): this is why the number of values is so small compared to other geophysical observations. The first estimates of the Earth gradient were given in the first part of the 19th century (Fourier, 1827), but the first heat flow measurements were reported only one century later by Bullard (1939) and Benfield (1939) for continents, and by Revelle and Maxwell (1952) for oceans. Then, the number of heat flow measurements increased regularly, allowing statistical analysis, global mapping and heat budgets (Chapman \& Pollack, 1975; Jessop et al., 1976; Sclater et al., 1980; Vitorello \& Pollack, 1980; Sclater et al., 1981; Stein \& Stein, 1992; Pollack et al., 1993). Up to the eighties, the heat flow community was active and well organized in the International Heat Flow Commission (IHFC) and produced regular compilations of data (Jessop et al., 1976; Hurtig et al., 1991; Cermak et al., 1992; Pollack et al., 1993) or guidelines to standardize and correct these data (Balling et al., 1981). But after the 1993 compilation (Pollack et al., 1993), the database was not maintained regularly by the IHFC, and only individual initiatives (Artemieva, 2006; Hasterok \& Chapman, 2008; Lucazeau \& Poort, 2015) tried to keep out an up-to-date record. One of these compilations (Hasterok \& Chapman, 2008) with 35,523 terrestrial measurements and 23,013 marine measurements is available online (http://www.heatflow.org/data). I started myself to maintain a database named NGHF (New Global Heat Flow), which has now grown to almost 70,000 values, while the Pollack's database only included 24,774 observations. The quality of the new measurements is usually better: marine techniques have been considerably improved with micro-computerized devices, in-situ measurements of thermal conductivity and multi-penetrations measurements colocated along seismic profiles (Hyndman et al., 1979; Von Herzen et al., 1989; Davis et al., 1997). In addition, new techniques have extended the domains of measurements on 
contintental margins, with the use of BSR (Bottom Simulating Reflectors) observations along high resolution seismic profiles (Yamano et al., 1982; Hyndman et al., 1992; Kaul et al., 2000; Lucazeau et al., 2004), and on mid-ocean ridges, with the use of short probes operated by submarine engines (H. P. Johnson et al., 1993; Becker et al., 1996) or thermal blankets (P. Johnson \& Hutnak, 1997; H. P. Johnson et al., 2010; Salmi et al., 2014). In the 2000s, the depletion of conventional oil reserves has stimulated the research on deep continental margins, including acquisition of new heat flow measurements (White et al., 2003; Lucazeau et al., 2004, 2008; Calvès et al., 2010); processing of oil exploration data to derive heat flow has also been improved by new techniques for estimating thermal conductivity from geophysical logs (Hartmann et al., 2005; Goutorbe et al., 2006; Fuchs \& Förster, 2013) or correcting bottom hole temperatures (Goutorbe et al., 2007). On land, several teams have maintained measurements activity (Mareschal \& Jaupart, 2004) and several regional compilations have identified heat flow data not included in Pollack's compilation (Hu et al., 2001; Tanaka et al., 2004; Blackwell \& Richards, 2004; Jiang et al., 2016, 2019).

Beside data collections, several attempts to extrapolate or predict heat flow from other observations have been developed. The most commonly used predictors are geology (Lee, 1965) and age (Chapman \& Pollack, 1975); recent analysis using them include Davies and Davies (2010) and Davies (2013), while Artemieva (2006) exclusively used them for continents. Elevation and age of the sea-floor constrain isostatic thermal models of the oceans (Sclater \& Francheteau, 1970; Parsons \& Sclater, 1977). Only few additional observations have been used as heat flow predictors: Shapiro and Ritzwoller (2004) extrapolated surface heat flow from upper mantle shear velocities, Li et al. (2017) used the Curie point depths based on EMAG2 and Hasterok et al. (2011) used distance to seamounts and sediment thickness as predictors for the efficiency of hydrothermal circulations. Goutorbe et al. (2011) extended the use of empirical predictors to an unlimited number of observations and tested different methods to combine them: the best results were obtained with a similarity method combining several proxies, which is also the most efficient in term of computational resources.

The objective of this paper is to present the state of the art for the Earth heat flow trends and suggest what could be further progress in the future. I analyze first the NGHF database and provide statistics that compare to previous studies. I reexamine also the heat flow age relationships that were debated for both oceans and continents. I finally discuss extrapolation of the surface heat flow to the entire Earth and propose a new global map at the resolution of $0.5^{\circ} \times 0.5^{\circ}$ based on a similarity method and suggest possible locations for future studies.

\section{The NGHF data set}

NGHF is a relational database powered by MariaDB (MYSQL fork), initially set up from the GLOBHEAT database (Pollack et al., 1993) and related to several other global databases (tectonic setting, age, basin types, crust or sediment thickness, etc...).

All the GLOBHEAT metadata were kept in NGHF, at least for comparisons with the initial data. While some of them duplicate information of the related databases (e.g. geology or geography), others remain useful (measurement techniques, quality) and were carefully reported, when available in publications. For instance, code 6 of GLOBHEAT reports the measurement quality, defined as the variation of heat flow with depth (A for a variation less than $10 \%$, B less than $20 \%$, $\mathbf{C}$ less than $30 \%$ and $\mathbf{D}$ greater than $30 \%$ ). This information is often not available in publications, but in that case, I attempted to derive it from a combination of other criteria (depth and number of measurements for instance). However, there still remains a large number of records with no information on the quality. 


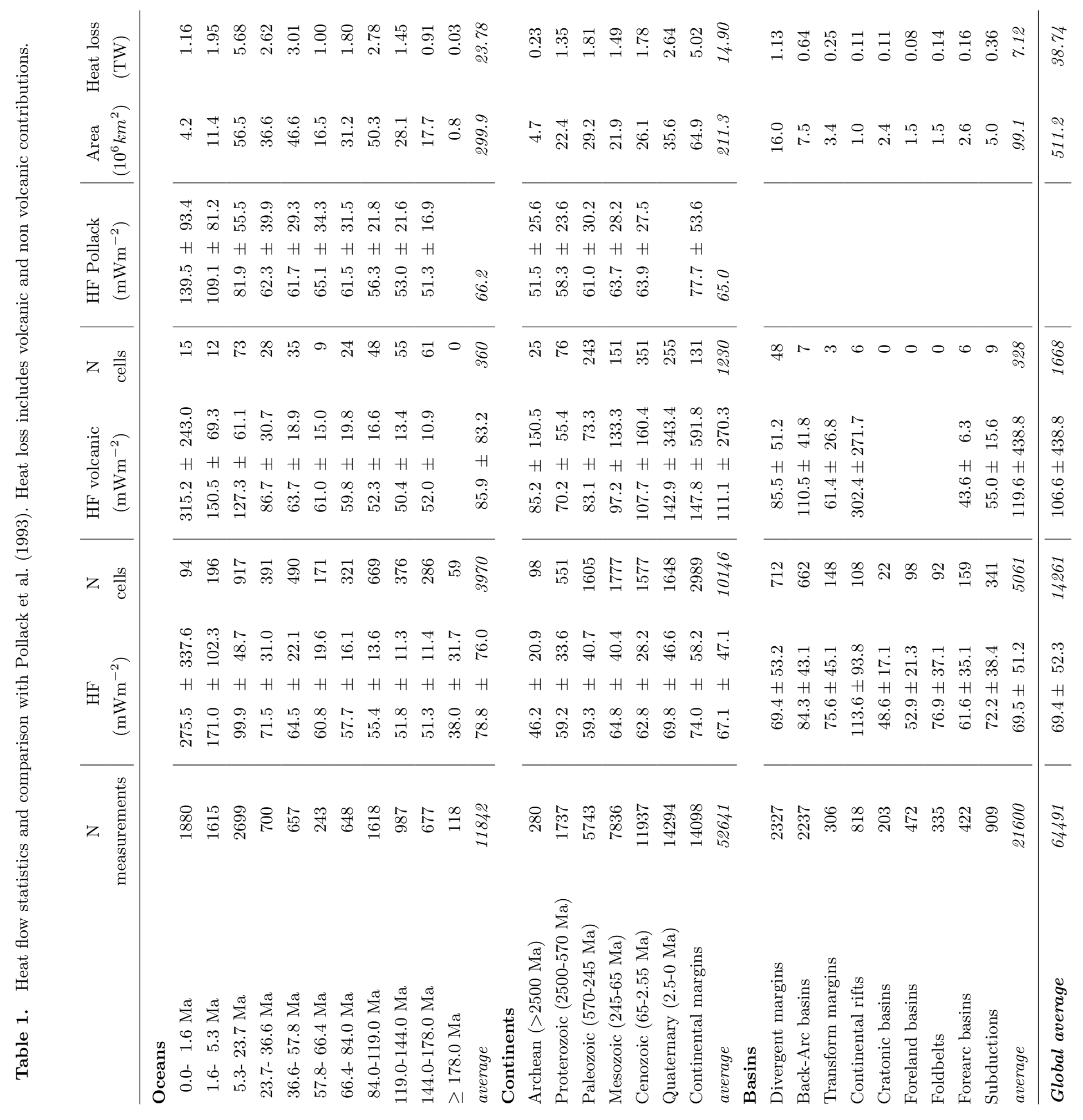


The new measurements added to NGHF are distributed all over the world and represent an enhancement of about $10 \%$ of the surface covered by data (more information on the distribution of the previous and new measurements is available in figures S1 and S2 of the supporting information). The database was cross-checked with that of Hasterok and Chapman (2008) and with the original publications, in order to identify misplaced or forgotten data, but as this can be done only manually, it takes time and the process is not yet achieved. On the other hand, an automatic check to remove redundant data was used to clean up the database. There is now a total of 29323 marine and 39901 terrestrial measurements, but 4702 very low quality measurements (D) were not used in this study.

As the distribution of data is quite uneven, two types of statistics were used, (1) arithmetic means for a selected province or a selected range of ages and (2) surfaceweighting averages on a $0.5^{\circ} \times 0.5^{\circ}$ grid. Arithmetic average and associated standard deviation are reported only for estimating the quality of distributions, for which histograms are also provided in figure S3 of the supporting information. The second method involves a first step making arithmetic mean (or preferentially median) $\overline{q_{i}}$ for each cell of the grid and then a second step making an average of heat flow weighted by the surface $A_{i}$ of each cell, which can vary with latitude:

$$
\bar{Q}=\frac{\sum_{i} A_{i} \overline{q_{i}}}{\sum_{i} A_{i}}
$$

As mentioned in Pollack et al. (1993), biases related to hydrothermal circulation exist in both oceans and continents. I show later in this paper that these biases have been reduced considerably in oceans thanks to the number of dedicated high resolution studies. On continents, some sites are already tagged as geothermal sites, but as this information is not systematic, I considered that measurements above a threshold of $250 \mathrm{mWm}^{-2}$ are also belonging to geothermal areas, which appeared an empirically relevant limit. This does not solve however the problem of downward percolation associated with low heat flow.

In the following paragraphs of this section, I provide statistics that can be compared to Pollack et al. (1993), and discuss the differences and the similarities with their study. I used the same oceanic and continental classifications (table 1), but as the origin of geological information is more recent, this could also introduce some differences in the analysis that are difficult to estimate. In this study, the age of oceanic seafloor is derived from Müller et al. (2008) unless it was mentioned in the original publications and the surface geology results from a compilation of USGS (2000) and UNESCO CCGM/CGMW (2000) shapefiles (figure 1a). In order to be consistent with Pollack et al. (1993), only areal statistics are presented in table 1 and are used in the calculation of global heat loss. However, median values, arithmetic averages and standard deviations are provided as quality estimators of the distributions. Statistics are also given both for normal lithosphere and lithosphere affected by intraplate volcanism (figure 1a).

In the oceanic domain, average values derived from NGHF are systematically higher than GLOBHEAT values for Cenozoic, but roughly similar for Mesozoic. At the locations where off-axis volcanism exists, there are also generally higher values for young ages of the seafloor that contribute to a significant increase of surface heat flow. The global heat loss of the oceanic domain can be extrapolated from the normal and volcanic areas of the Earth, and their respective ages. The resulting value is significantly higher $(23.8 \mathrm{TW})$ than for Pollack (19.7 TW). The quality of measurements has a significant effect on the statistics and oceanic heat loss. Quality A data (heat flow variation less than $10 \%$ with depth) have an arithmetic mean of $126.3 \pm 235.4$ $\mathrm{mWm}^{-2}$, compared to $177.4 \pm 434.5 \mathrm{mWm}^{-2}$ for all measurements except the D category, but conversely, the surface-weighted average is higher for quality A (87.3 \pm 
$132.3 \mathrm{mWm}^{-2}$ vs $78.8 \pm 76.0 \mathrm{mWm}^{-2}$ ), which increases the oceanic heat loss to 26.4 TW. As the quality of measurements significantly increased when electronic devices were introduced in instruments (in the 90's), the date of publication can also be used to filter out the lesser quality data. Additionnally, the improvement of seismic imaging techniques allowed a better positioning of heat flow measurements, where a thick sediment cover protects basement from hydrothermal circulation. For measurements after 1990, the surface weighted-average values is $84.2 \pm 114.1 \mathrm{mWm}^{-2}$ and $90.0 \pm$ $198.1 \mathrm{mWm}^{-2}$ if combined with category A. On the other hand, if the Hasterok et al. (2011) criterion (sediment thickness greater than $400 \mathrm{~m}$ and distance to the closest seamount greater than $60 \mathrm{~km}$ ) is used to exclude areas affected by hydrothermal circulation, the oceanic average heat flow decreases because a large number of high value near ridges axis are excluded. This can be overcome if the criterion is not applied to ages between 0 and 1.6 Ma: in that case, the surface-weighted average heat flow increases to $82.5 \pm 106.7 \mathrm{mWm}^{-2}$ and $88.1 \pm 181.9 \mathrm{mWm}^{-2}$ for category A only. A topographic ruggedness criterion was also proposed by Le Gal et al. (2018) to identify areas affected by hydrothermal circulation. This criterion is based on the variogram sill of topography (elevation difference at a given distance): the authors showed that for a sill greater than $\sim 75 \mathrm{~m}$, heat flow is largely affected by hydrothermal processes. However, the method is hardly suitable for a global analysis, and instead, I used a simpler ruggedness index (Wilson et al., 2007) with a threshold value of $50 \mathrm{~m}$. In that case, oceanic heat flow average is $83.1 \pm 99.1 \mathrm{mWm}^{-2}$ and $89.1 \pm 173.0 \mathrm{mWm}^{-2}$ for category A only.

The best quality (category A, published after 1990, associated with a significant sediment thickness) oceanic measurements averages suggest therefore that the oceanic heat flow is at least $88-90 \mathrm{mWm}^{-2}$ and the oceanic heat loss $>27 \mathrm{TW}$.

In the continental domain, average values are relatively similar to those obtained by Pollack et al. (1993), but NGHF averages are again higher for Cenozoic, especially for regions affected by volcanism. A large number (22184) of data derived from oil exploration was included in the new database, but this did not introduce a significant bias as the weighted averages are relatively similar. The arithmetic mean is slightly lower for oil data $\left(62.4 \pm 21.3 \mathrm{mWm}^{-2}\right)$ than for non oil data $\left(68.4 \pm 45.5 \mathrm{mWm}^{-2}\right)$. The statistical effect related to the measurements quality is also limited: the arithmetic mean of quality A data (heat flow variation less than $10 \%$ with depth) is $68.3 \pm 37.9$ $\mathrm{mWm}^{-2}$ compared to $62.2 \pm 41.2 \mathrm{mWm}^{-2}$ for quality D data (heat flow variation higher than $30 \%$ ), which have not been included however in the present study. The global continental heat loss is slightly higher (14.9 TW) than the Pollack estimate (13.9 TW).

The total Earth heat loss based on the NGHF heat flow measurements is $\sim 38.7$ TW (33.6 TW for Pollack), and up to $42.0 \mathrm{TW}$ with the highest quality oceanic data. This is very similar to previous estimates using a conductive cooling model for the oceanic domain instead of heat flow data (Sclater et al., 1981; Pollack et al., 1993; Sclater et al., 2014; Jaupart et al., 2015), which would lead to 44-45 TW with the NGHF dataset.

In addition, I provide in table 1 statistics for sedimentary basins, where heat flow is often estimated from oil exploration wells. The average is comparable to the global average (table 1), which confirms that oil data do not add substantial statistical bias, as the lower quality of temperature estimates is probably balanced by the greater depth of measurements. The variations of heat flow within sedimentary basin types are relatively straightforward, with the highest values for active extensional areas (rifts, back-arc basins) and the lowest values for convergent areas (foreland and forearc basins) and cratonic basins. 


\section{Oceanic heat flow}

The NGHF database contains 15333 oceanic data, ranging from -302 to 33448 $\mathrm{mWm}^{-2}$, with an arithmetic average $\mathrm{HFa}=205 \pm 672 \mathrm{mWm}^{-2}$, a median value $\mathrm{HFm}=78.2 \mathrm{mWm}^{-2}$ and a surface weighted average $\mathrm{HFw}=70.8 \mathrm{mWm}^{-2}$. The large range (including negative values) and the large standard deviation associated with the arithmetic average are mostly related to the non conductive processes near mid ocean ridges. When the lowest quality measurements (category D) are excluded, the number of values decreases to 11842 , with an arithmetic average $\mathrm{HFa}=179 \pm$ $425 \mathrm{mWm}^{-2}$, a median value $\mathrm{HFm}=80.4 \mathrm{mWm}^{-2}$ and a surface weighted average $\mathrm{HFw}_{\mathrm{w}}=79.3 \mathrm{mWm}^{-2}$. Histograms of the heat flow distribution are shown in figure S3 of the supporting information. These average values (table 1) are significantly higher than in Pollack et al. (1993), but this is mainly related to Cenozoic for which new measurements have a better quality and a better spatial distribution. However, the data coverage remains only $2.7 \%$ of the Earth surface $(4.6 \%$ of the global ocean surface) on a $0.5^{\circ} \times 0.5^{\circ}$ grid (see table S7 in supplementary material). Extrapolation of the average value $\mathrm{HFw}$ to the Earth ocean surface leads to an oceanic heat loss of 23.8 TW compared to 18.5 TW for Pollack et al. (1993) and as discussed previously, rises up to $27 \mathrm{TW}$ if one only considers the most recent data (publications starting in 1990).

The decrease of heat flow with age and the subsidence of the sea floor are usually interpreted as a result of the passive cooling of oceanic lithosphere from the accretion ridge. Subsidence of the sea floor is therefore a major constraint on the oceanic thermal regime, because it is less affected by superficial processes than the surface heat flow: the most important of these effects is related to hydrothermal circulation, which has a dramatic mining effect where the impermeable sediment cover is not thick and continuous enough to prevent the recharge of sea water in a highly permeable upper crust (Lister, 1972; Davis et al., 1992; Villinger et al., 2002).

The first analysis of the ocean topography discussed whether the lithosphere was cooling continuously according to a boundary layer model (Davis \& Lister, 1974) or reached a limit after a certain time like a plate model (Parsons \& Sclater, 1977). The flattening of subsidence for $\sim 80$ Ma age (Parsons \& Sclater, 1977) promoted the plate model rather than the boundary layer model in further analyses, but conversely the assumption of a constant temperature at the base of the lithosphere requires additional heat sources, such as the onset of small scale convection (Davaille \& Jaupart, 1994) or lithosphere reheating (Menard \& McNutt, 1982; Nagihara et al., 1996).

Different approaches were used to process heat flow and topographic data. While Parsons and Sclater (1977) selected only high quality data, Stein and Stein (1992) used a global statistical approach, which led to significantly different results. Both studies promoted the plate model, which explains the flattening of the topography for old ages of the sea floor, but the lithosphere was significantly hotter and thinner in the Stein and Stein (1992) analysis. Parsons and Sclater (1977) had a best fit using a 125 $\mathrm{km}$ thick plate with $1333{ }^{\circ} \mathrm{C}$ at the bottom, while Stein and Stein (1992) suggested $95 \mathrm{~km}$ and $1450{ }^{\circ} \mathrm{C}$, which is too high for the average composition of MORB and the average thickness of oceanic crust (McKenzie et al., 2005; Jaupart et al., 2015). Hillier and Watts (2005) reexamined bathymetry of the North Pacific using a filtering method to remove components of the topography that are not related to thermal contraction. They found that the flattening occurs for older age (85 Ma) than Stein and Stein (1992), but still observed a deviation from the boundary layer model. The importance of the processing method was recently reopened by Adam and Vidal (2010) who analyzed bathymetry along trajectories representative of the underlying mantle flow and obtained conversely a better agreement with the boundary layer model. On the other hand, Goutorbe (2010) adding constraints provided by shear waves velocities in the upper mantle, preferred a constant heat flow at the base of the lithosphere 
a)

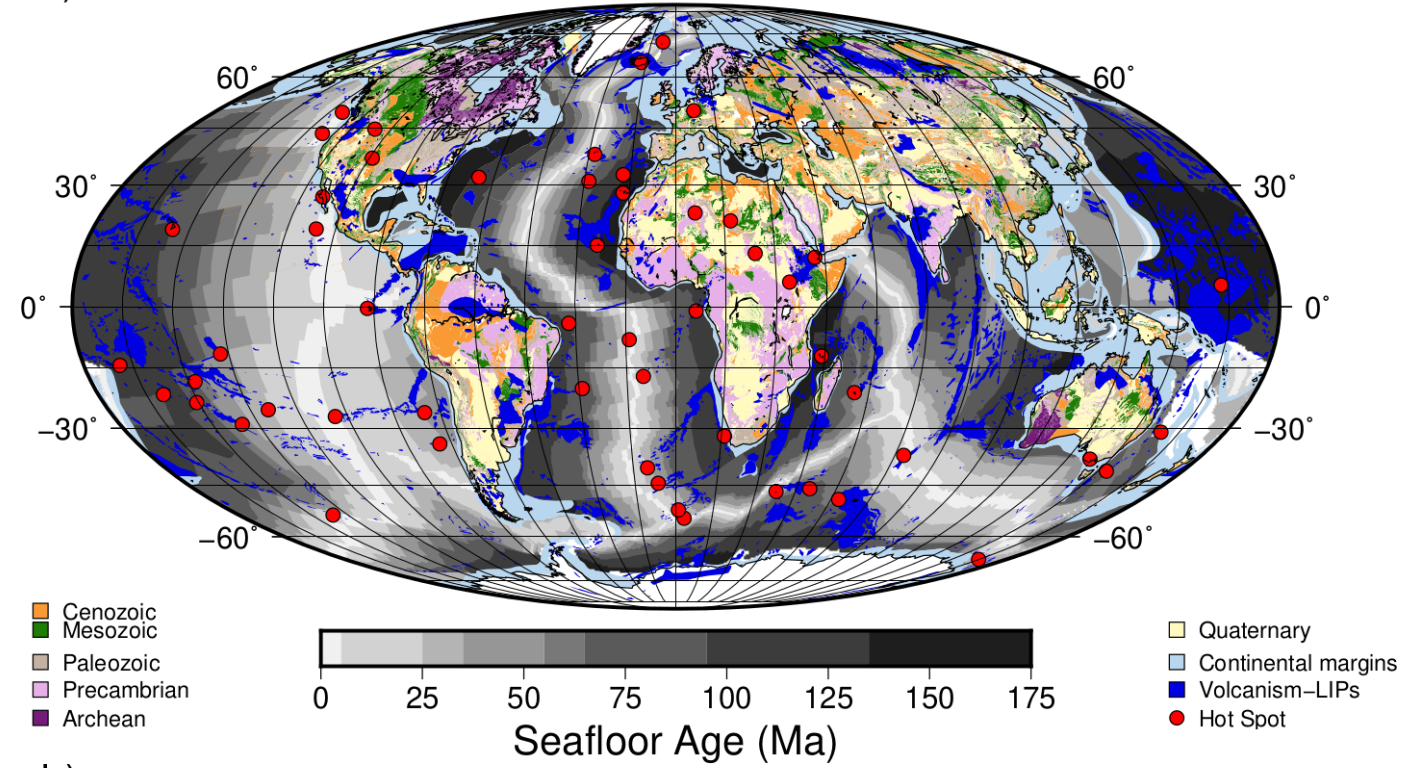

b)

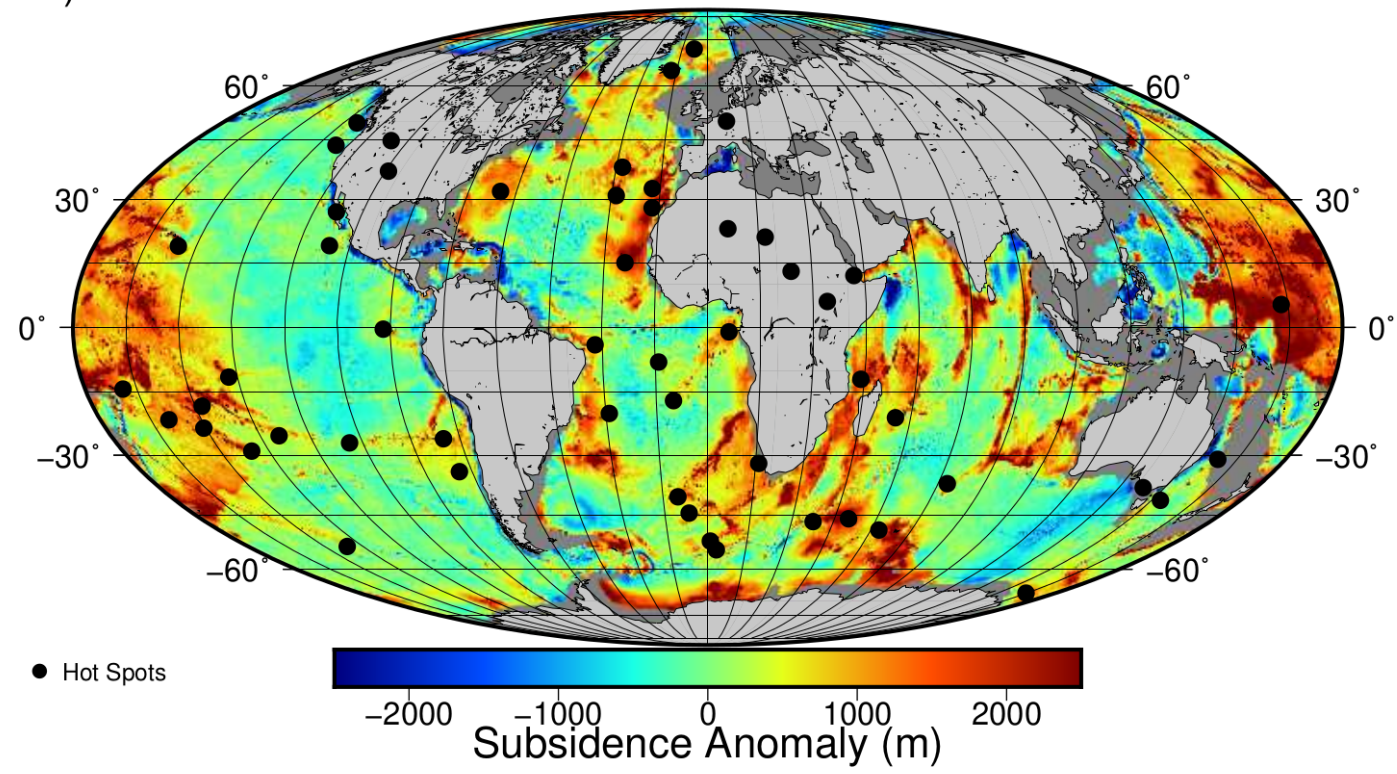

Figure 1. a) Age of continents (CCGM/CGMW, 2000) and oceans (Müller et al., 2008) used in the statistical analysis of this paper. The scale refers to the age of seafloor (in Ma). Red dot are the main hot spots, and blue color corresponds to LIPs or flood basalts (Johansson et al., 2018). b) Anomalies of subsidence (in meters) with respect to the elevation $\mathrm{h}$ given by the boundary layer model with Parsons and Sclater (1977) values: $\mathrm{h}=2500+350 \sqrt{\mathcal{T}}$ where $\mathcal{T}$ is the age of the sea floor (Ma). Positive anomalies are mostly related to hot spots locations, hot spots tracks or large igneous provinces (see figure 1a for the location of LIPs). 
(CHABLIS), initially proposed by Doin and Fleitout (1996). Other studies (Goutorbe \& Hillier, 2013; Grose \& Afonso, 2013; Hasterok, 2013) examined the effects of filtering global topography of the oceans or the effect of parameters values on the model results, but did not resolve the question of why there are so much difference between observed subsidence on selected oceanic domains as in Parsons and Sclater (1977) or Adam and Vidal (2010), and subsidence obtained from global topography of oceans.

In the present study, I reexamine this paradox and I started to reprocess topography at heat flow sites only. In most cases, I used topography as given at these sites in the publications, otherwise GTOPO30 was used. In order to have comparable subsidence estimates, topography was corrected for sediment loading (Le Douaran \& Parsons, 1982) and for variations of the crustal thickness:

$$
S=Z+e_{\text {sed }} \frac{\rho_{m}-\rho_{s}}{\rho_{m}-\rho_{w}}+\left(e_{\text {crust }}-e_{\text {ref }}\right) \frac{\rho_{m}-\rho_{c}}{\rho_{m}-\rho_{w}}
$$

where $S$ and $Z$ are respectively the corrected and uncorrected topography, $e_{\text {sed }}$ the sediment thickness, $\rho_{m}$ the mantle density, $\rho_{s}$ the sediment density, $\rho_{w}$ the sea water density, $\rho_{c}$ the oceanic crust density, $e_{\text {crust }}$ the local crustal thickness and $e_{\text {ref }}=6 \mathrm{~km}$ the reference thickness of the crust. The sediment thickness was obtained from global maps (Divins, 2003; Whittaker et al., 2013) when no other information was available and the crustal thickness from CRUST1.0 (Laske et al., 2013).

Heat flow was binned for variable time intervals $\Delta t$, increasing with the age of the sea-floor, in order to have a better definition for young ages for which heat flow varies the most:

$$
\Delta t=(2 i-1) \Delta t_{0}
$$

where $\mathrm{i}[1,126]$ is the $\mathrm{i}^{\text {th }}$ age interval and $\Delta t_{0}=0.011236 \mathrm{Ma}$ ( $\mathrm{t}$ varying from 0 to $178.4 \mathrm{Ma})$.

The resulting sea floor subsidence is significantly different from that predicted by GDH1 for age $>65$ Ma but in good agreement with PS model (figure 2) or the more recent analysis of Richards et al. (2018), which selected 2,028 reliable sites where sediment thickness and crustal thickness are well known. In order to check if these differences were related to methodological problems, the same analysis was performed using just the global topography (GTOPO30). In this case, the agreement with GDH1 is excellent (figure 2). Additionally, bathymetry at selected sites in the North Pacific and for ages of the sea floor $>100 \mathrm{Ma}$ (Parsons \& Sclater, 1977) is in good agreement with the trend defined by bathymetry at heat flow sites. On the other hand, heat flow measurements are more consistent with the GDH1 model. I conclude therefore that (1) the heat flow measurements do not sample a representative surface of the oceanic domains, and (2) the existing models using global topography datasets do not provide a good fit for subsidence at heat flow sites.

Where the oceanic subsidence derived from GTOPO30 differs from the trend defined at heat flow sites only can be directly mapped as the difference between the Parsons and Sclater (1977) model and the observed topography (figure 1). The maximum deviations $(>+2000 \mathrm{~m})$ are all observed in the vicinity of hot spots, hot spots tracks, swells or large igneous provinces, like the Western Pacific around Ontong Java plateau, the African margins, the Crozet or Reunion swells and many other volcanic areas. In these anomaleous zones, the average bathymetry is only $2500 \mathrm{~m}$ and the average age is 108 Ma. There are only a few heat flow measurements in these zones (41/15333 values and $34 / 5321$ cells), which explains why subsidence at heat flow sites is so different from global data. However, the average heat flow $\left(52.8 \pm 16.4 \mathrm{mWm}^{-2}\right)$ in these anomalous subsidence areas is not very different from that observed elsewhere on the old oceanic lithosphere. 
The origin of the subsidence anomalies is obviously not related to crustal isostasy, since the variations of crustal thickness as well as the sediment load were corrected before. The coincidence with hot spots, LIPs or intraplate volcanic zones suggests that it is rather connected to residual thermal anomalies after an event that partially or totally reset the thermal state of the lithosphere (Menard \& McNutt, 1982; Detrick \& Crough, 1978) or to dynamic topography. The latter possibility does not seem however a likely explanation as the present day dynamic topography (Moucha et al., 2008 ) is totally uncorrelated with the anomalous subsidence. Nagihara et al. (1996) proposed a reheating process to explain heat flow and subsidence discrepancy with the PS model for an old oceanic lithosphere. As in the present study, they observed that heat flow is more consistent with GDH1 and subsidence with PS, but they interpreted the higher heat flow with respect to the PS model as a result of thermal reheating. In their interpretation, the surface heat flow would be perturbed by reheating of the lithosphere, but subsidence would follow the normal trend given by the PS model. My interpretation is different, and I rather postulate that reheating has affected specific zones (hot spots, LIPs), but that most of the data are characterized by a normal behavior that none of the existing models explains.

Therefore, as no existing model can match simultaneously heat flow and subsidence obtained at the same sites, I used a numerical model that provides more flexibility on parameters, and a Monte Carlo procedure to get their optimal values. The thermal model is a stationary and Eulerian 2D finite element model with a constant surface temperature, a temperature condition at the accretion axis, no heat flow through the other vertical boundary condition at a distance equivalent to 2 times the actual size of oceans and either a temperature or heat flow condition at the base of the box (figure 3). An advection term accounts for the thermal effect of oceanic accretion at a constant horizontal plate velocity $\mathrm{V}$.

$$
\frac{\partial}{\partial x}\left(\lambda(T, z) \frac{\partial T}{\partial x}\right)+\frac{\partial}{\partial z}\left(\lambda(T, z) \frac{\partial T}{\partial z}\right)-\rho C(z, T) V \frac{\partial T}{\partial x}=0
$$

where $\mathrm{T}$ is the temperature, $\mathrm{x}$ the horizontal dimension, $\mathrm{z}$ the vertical dimension, $\rho$ the density of the lithosphere, $\mathrm{C}$ the specific heat. The mesh is irregular and more refined near the ridge axis and near the surface (same progression as in equation 3). At the accretion axis, temperature of the mantle is a free parameter that decreases linearly in the upper $6 \mathrm{~km}$ of the lithosphere before reaching the surface temperature condition, for both numerical stability and to account for an accelerated cooling by hydrothermal processes in the crust like in Cochran and Buck (2001) or Spinelli and Harris (2011).

$$
T(0, z)=T_{L}
$$$$
\text { for } z_{c} \geq z \leq L
$$

$$
T(0, z)=T_{L}-\frac{T_{L}-T_{s}}{z_{c}}\left(z_{c}-z\right) \quad \text { for } z<z_{c}
$$

where $\mathrm{x}=0$ is the accretion axis, $T_{L}$ the temperature of the mantle, $T_{s}$ the surface temperature, $z_{c}$ the thickness of the crust and $\mathrm{L}$ the depth of the lower boundary condition. The upper part of the lithospheric mesh is formed by a $6 \mathrm{~km}$ thick basaltic crust, which has a lower density $\left(\rho=2850 \mathrm{Kg} \mathrm{m}^{-3}\right)$ and a lower thermal conductivity $\left(\lambda_{c}=3.0 \mathrm{Wm}^{-1} \mathrm{~K}^{-1}\right)$ than the lithospheric mantle. The importance of this insulating lid has been outlined by Grose and Afonso (2013), and leads to a significantly warmer lithosphere but lower heat flow for young ages of the seafloor (0-35 Ma).

As outlined by McKenzie et al. (2005), the thermal dependence of thermal conductivity including radiative transfer changes significantly the distribution of mantle temperatures and was included in the calculation. The radiative component differs significantly between two end-member models (Schatz \& Simmons, 1972; Hofmeister, 1999) for high temperatures (see figure S4 in the supporting information), but the differences for the lithospheric thermal regime remain negligible. 
a)

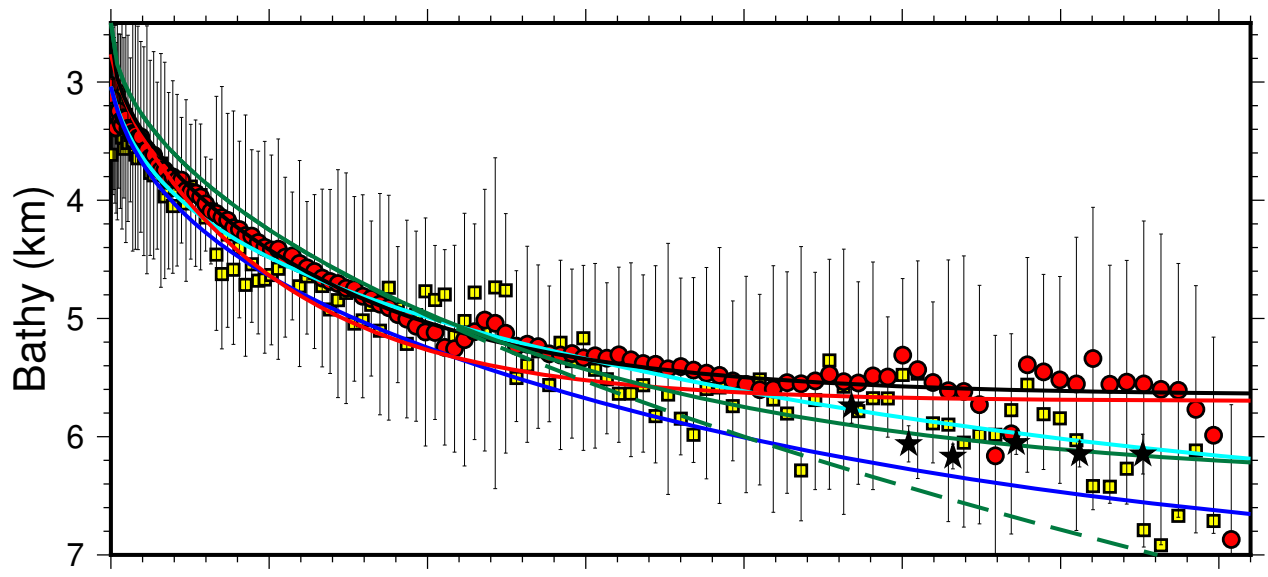

b)

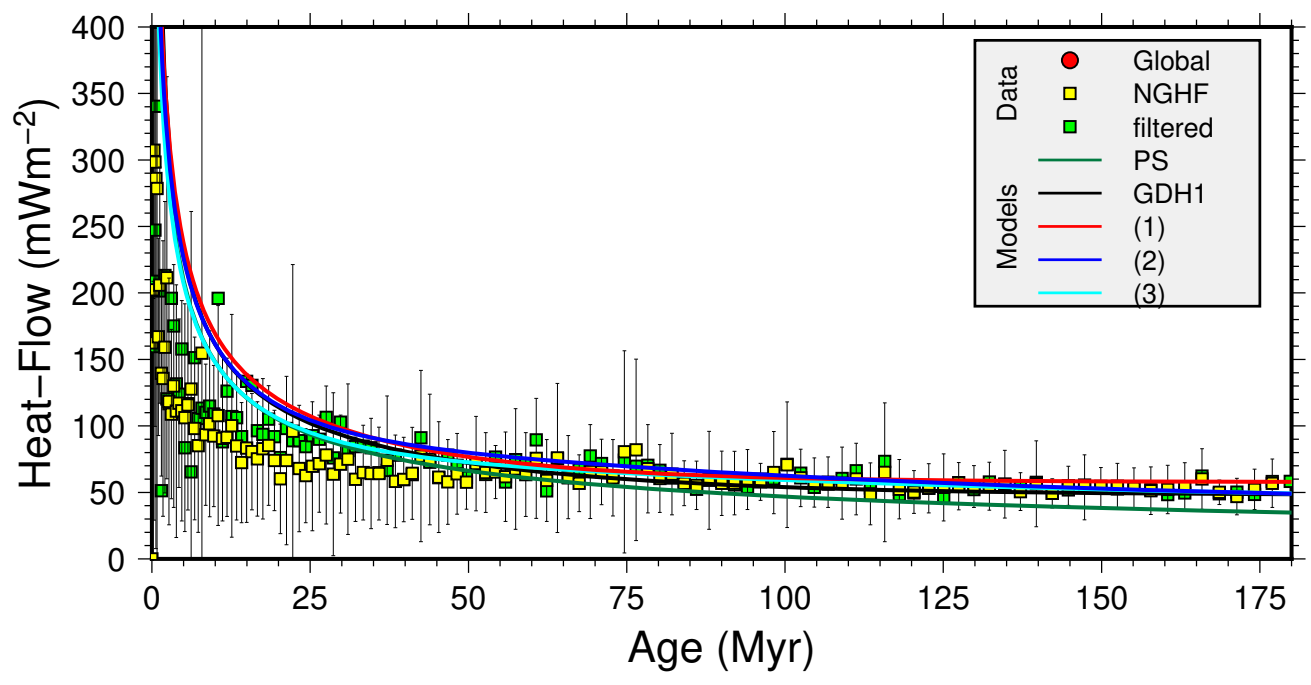

Figure 2. a) Elevation versus age of the ocean floor. Red and yellow symbols are respectively subsidence data from the global coverage and from a subset of locations where heat flow measurements exist. Both are corrected for sedimentation and crustal thickness variations and averaged for increasing time intervals. Stars are selected sites from North Pacific from the Parsons and Sclater (1977) paper. Lines correspond to models, black line to GDH1 (Stein \& Stein, 1992), green line to PS (Parsons \& Sclater, 1977), green dash line to boundary layer model and other color lines to numerical models (see text for details); b) heat flow versus age of the ocean floor; the green symbols correspond to filtered heat flow data in the same way as Hasterok et al. (2011), with sediment thickness and distance to the closest seamount larger than $400 \mathrm{~m}$ and $60 \mathrm{~km}$ respectively. 
Because of the lateral heat conduction in the model, low plate velocities $(<8$ $\mathrm{km} / \mathrm{Ma}$ ) result in higher surface heat flow near the ridge axis than in 1D models (see figure S5 in the supporting information. In this study, I used therefore a velocity ( 8 $\mathrm{km} / \mathrm{Ma}$ ) that makes $2 \mathrm{D}$ results as close as possible with $1 \mathrm{D}$ models.

Subsidence of the sea floor results from thermal contraction when the lithosphere cools down and is obtained by integration of the density anomalies with respect to the ridge axis, using a local Airy assumption.

$$
S_{\text {calc }}=\frac{\int_{0}^{Z_{L}} \rho(0, z, T) \partial z-\int_{0}^{Z_{L}} \rho(x, z, T) \partial z}{\rho_{a}-\rho_{w}}
$$

with a temperature dependence of density:

$$
\rho(T)=\rho_{0}(1-\alpha T)
$$

and with $\rho_{a}=\rho\left(T_{L}\right)$. The coefficient of thermal expansion $\alpha$ fitting lithosphere subsidence in previous studies $\left(\sim 3.1-3.2 \times 10^{-5} \mathrm{~K}^{-1}\right)$ is generally $15-30 \%$ lower than determined experimentally (Korenaga, 2007; Goutorbe \& Hillier, 2013; Grose \& Afonso, 2013). The origin of this reduction is not still well understood, and, here, I preferred to use it as a free parameter that makes comparison with conventional models easier. I let also specific heat constant, in order to minimize the number of free parameters.

Several other free parameters (table 2) were randomly selected using a Monte Carlo procedure in order to minimize the misfit with subsidence in the range 0-180 $\mathrm{Ma}$ and the misfit with heat flow in the range 75-180 Ma. A unique estimator of the misfit was defined as:

$$
R M S=\sqrt{\left.\left(\frac{\left(S_{o b s}-S_{c a l c}\right)^{2}}{S_{r e f}^{2}}\right)_{[0,180 M a]}+\left(\frac{\left(H F_{o b s}-H F_{c a l c}\right)^{2}}{H F_{r e f}^{2}}\right)_{[75,180 M a}\right]}
$$

where $S_{o b s}$ is the observed subsidence, $S_{\text {calc }}$ the corresponding modeled subsidence, $H F_{\text {obs }}$ the observed surface heat flow, $H F_{\text {calc }}$ the modeled surface heat flow, and $Z_{\text {ref }}$ and $H F_{\text {ref }}$ are arbitrary values for normalization, respectively $5000 \mathrm{~m}$ and $40 \mathrm{mWm}^{-2}$. The choice of the type of lower boundary condition (temperature or heat flow) is also randomly chosen.

Three cases of subsidence curves are investigated here: (1) corresponds to the global set of topographic data, (2) to a subset of topographic data at heat flow sites only and (3) to the global set of topographic data, for which locations with subsidence anomalies $>+2000 \mathrm{~m}$ were removed.

The optimal fit for case (1) corresponds to a fixed temperature at the base of the box (plate model) and is the closest of my results to the GDH1 model in term of subsidence flattening, but with a more pronounced curvature (figure 2). However, the optimal thickness $(119 \mathrm{~km})$ and mantle temperature $\left(1300{ }^{\circ} \mathrm{C}\right)$ are different from those of GDH1 and more similar to the McKenzie et al. (2005) model (106 km and 1315 ${ }^{\circ} \mathrm{C}$ ), which also included the temperature dependence of thermal conductivity. Mantle thermal conductivity is high but fits the experimental results on sintered forsterite in Schatz and Simmons (1972) (see figure S4 in supporting information). The heat flow for old ages of the sea floor is also significantly higher than GDH1 (figure 2).

The optimal fit for case (2) corresponds to a constant heat flow $36.4 \mathrm{mWm}^{-2}$ at the base of a $114 \mathrm{~km}$ thick lithosphere. Compared to the plate model for case (1), the temperature decreases faster near the axis and the slope of isotherm $600{ }^{\circ} \mathrm{C}$ is in very good agreement with the distribution of intraplate earthquakes (figure 3) published by McKenzie et al. (2005). 
Table 2. Parameters of the numerical model, including the a priori ranges and the best a posteriori values. Mantle conductivity $\lambda_{L}$ is the value at surface temperature; its dependence with in situ temperature includes a lattice component given by $\lambda_{L}(T)=\lambda_{L}(1+\nu \Delta T)^{-1}$ where $\nu=1.25 \cdot 10^{-3} K^{-1}$ and a radiative component. A map of all optimal values is also provided in supporting information. RMS is obtained according to equation 9. RMS values in parentheses correspond to subsidence only.

parameter symbol
(1)

$2.7010^{-5}$
119
1300
0
2.82
4.85

$1.17(0.41)$

$2.46(0.70)$

30.3
(2)

$3.0610^{-5}$
114
1235
36.4
3.04
4.64

$3.0910^{-5}$ 118

1170

37.1

3.01

5.25

$(3)$

unit

$\begin{array}{cc}0.89(0.31) & 0.75(0.06) \\ 1.40(0.88) & 1.27(0.63) \\ 2.49(0.80) & 2.41(0.51) \\ 29.8 & 27.5\end{array}$

$\mathrm{K}^{-1}$
$\mathrm{~km}$
${ }^{\circ} \mathrm{C}$
$\mathrm{mWm}^{-2}$
$\mathrm{~km}^{-1} \mathrm{~K}^{-1}$

$\begin{array}{ccc}\alpha & 2.710^{-5} & 3.310^{-5} \\ \mathrm{~L} & 90 & 120 \\ \mathrm{~T}_{L} & 1170 & 1430 \\ \mathrm{q}_{L} & 27 & 33 \\ \mathrm{~h}_{0} & 2.800 & 3.400 \\ \lambda_{L} & 3.50 & 5.50\end{array}$

RMS

RMS GDH1

RMS PS

Heat loss

Thermal expansion
Boundary condition
Bottom temperature
Bottom heat flow
Ridge elevation
Mantle conductivity
RMS
RMS GDH1

Heat loss

The optimal fit for case (3) corresponds to a constant heat flow $37.1 \mathrm{mWm}^{-2}$ at the base of a $118 \mathrm{~km}$ thick lithosphere. As for case (1) and (2), mantle thermal conductivity is high but still in line with Schatz and Simmons (1972) results (see figure S4 in supporting information).

The RMS misfit only for heat flow / age (excluding subsidence) is less for cases (2) and (3) involving a basal heat flow boundary condition than for the plate model (1): these models can account for a slow decrease of heat flow for ages $>65 \mathrm{Ma}$ while the plate model predicts an almost constant value, that becomes higher than observations at oldest ages of the seafloor. Using the same RMS criteria, the GDH1 and PS models do not provide as good adjustment as numerical results, mostly because heat flow differs more significantly. As noticed before, the PS model heat flow is systematically lower than measurements, while GDH1 is close to case (2) for ages $<40 \mathrm{Ma}$ and for ages $>150$ Ma. Several other studies have explored different effects related to parameters values or different filters applied to topography of the seafloor. For instance, Grose and Afonso (2013) explored, through a sophisticated 2D numerical model, the effects of physical properties based on mineral physics and chemistry. They also accounted for axial hydrothermal circulation and for the effect of oceanic crust as a thermal insulator. Their models do not require an important reduction of the coefficient of thermal expansion as other studies (including this one), but they still need a reduction of $15 \%$. Although a direct comparison with their results is difficult, their conclusion on a cooler lithosphere than GDH1 model for seafloor younger than $35 \mathrm{Ma}$ is similar to model (1), but their estimate of the oceanic heat loss (27 TW) is lower than model (1). On the other hand, as they do not consider models with a bottom heat flow condition, a comparison with model (2) and (3) is not possible. Compared to CHABLIS models, which imposes a constant heat flow at the base of an isotherm, bottom heat flow values in models (2) and (3) are similar to Doin and Fleitout (1996) and Goutorbe (2010).

The total oceanic heat loss corresponding to models (2) and (3) is 29.8 and 27.5 TW. This does not include however a potential additional heat flow related to reheating 
$\mathrm{T}_{0}$

a)

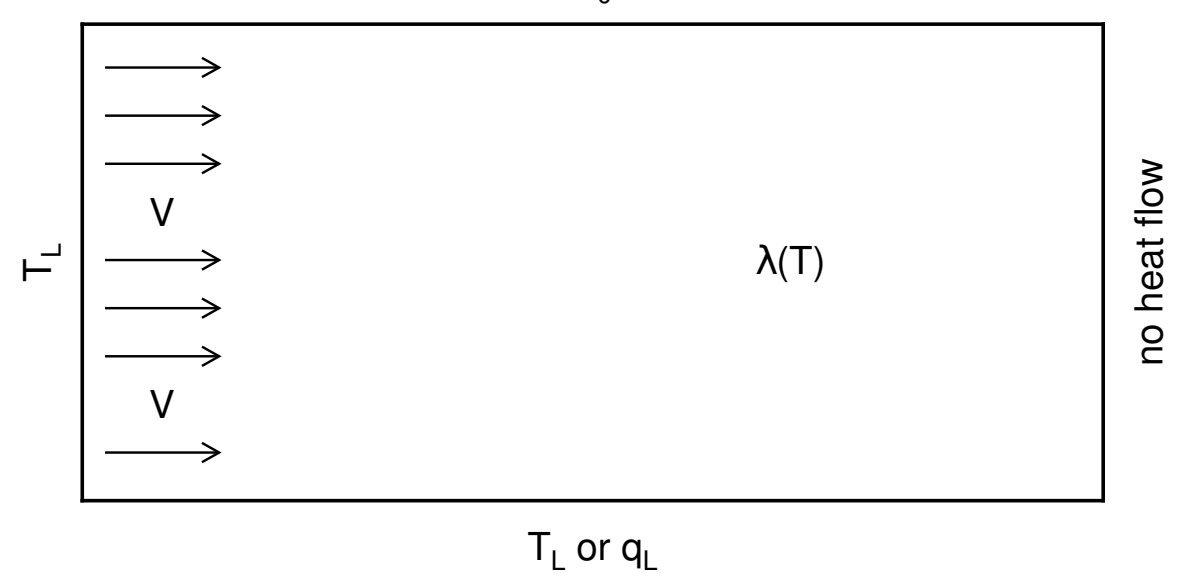

b)

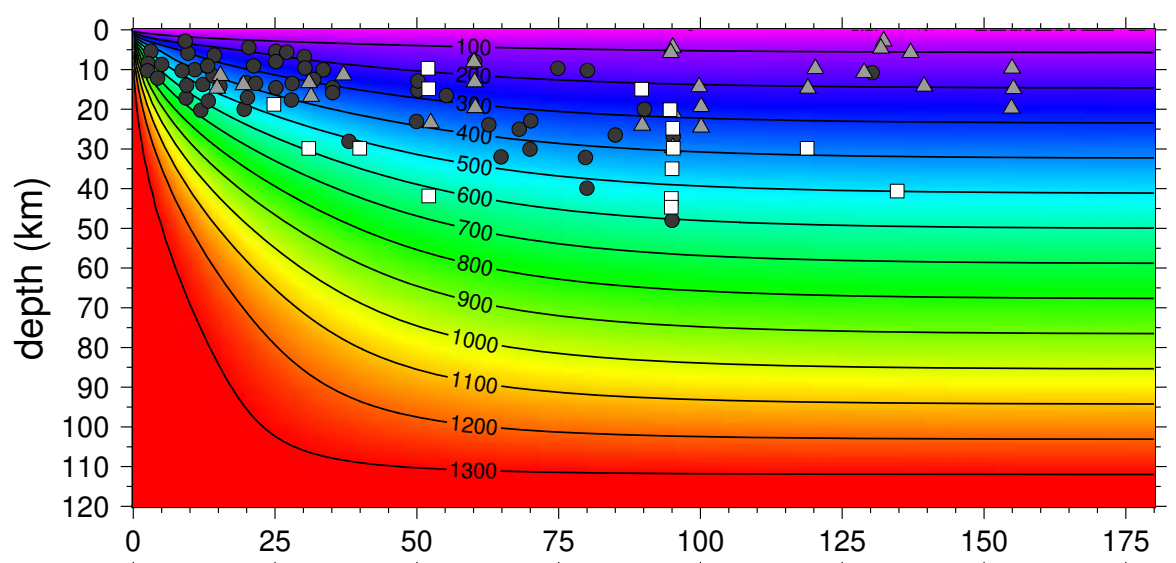

c)
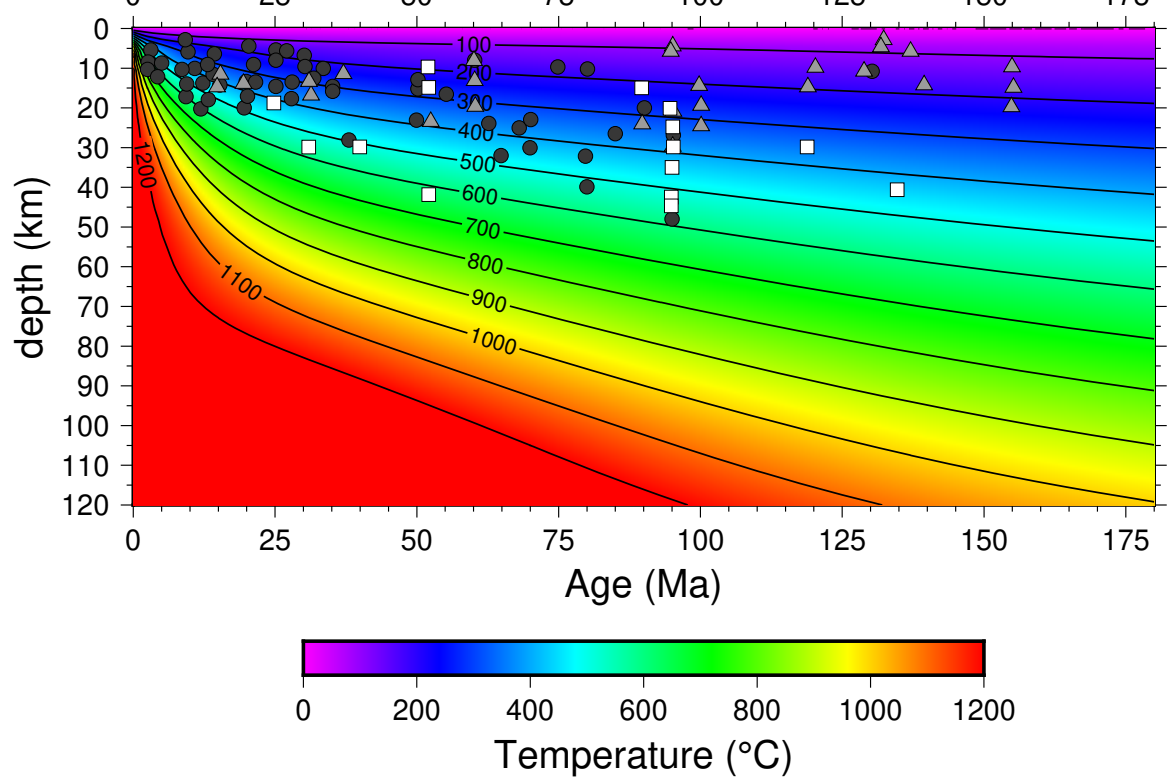

Figure 3. a) Finite element model sketch. The box width is $2 \mathrm{~V} \mathrm{t}_{\max }=2 \times 8 \mathrm{~km} / \mathrm{Ma} \times 180$ $\mathrm{Ma}=2880 \mathrm{~km}$ and the box height is L. The lower boundary condition is either a fixed temperature $\mathrm{T}_{L}$ or heat flow $\mathrm{q}_{l}$. Parameters values are given in table 2 ; b) lithospheric temperature field for model (1) with temperature as a lower boundary condition; c) lithospheric temperature field for model (2) with heat flow as a boundary condition. The dots (intraplate), triangles (outer rises) and squares (thrusts in outer rises) symbols show the depths of earthquakes within the oceanic lithosphere whose depths have been constrained by waveform modeling (McKenzie et al., 2005). 
of the lithosphere, in regions where the subsidence anomaly exceeds $+2000 \mathrm{M}$ (figure $1 b)$.

Several studies estimated the hydrothermal heat flow as the difference between conductive heat flow derived from thermal models and the observed heat flow. In the Stein and Stein (1992) study, this difference is significant for ages $<65$ Ma and increases progressively with decreasing ages to reach $60 \%$ of the conductive heat flow near the ridge axis. The threshold at $65 \mathrm{Ma}$ was interpreted as a possible permeability closure in the uppermost lithosphere, which could limit hydrothermal circulation for older ages of the sea floor, but several studies showed that such a permeability change occurs more likely closer to the ridge axis (Fisher, 1998) and that the heat flow may be perturbed by hydrothermal circulation for older ages of the sea floor (Von Herzen, 2004; Fisher \& Von Herzen, 2005). The addition of new measurements or the filtering of these measurements (Hasterok et al., 2011) can also change the resulting magnitude of hydrothermal heat flow and/or the position of the permeability threshold (figure 2 ). I report in figure $4 \mathrm{~b}$ the difference between a conductive model and the bins with measurements obtained after 1990: the threshold would be near $20 \mathrm{Ma}$ and the total hydrothermal heat loss less than 2 TW! It seems therefore difficult to estimate the oceanic hydrothermal heat loss as the difference between a conductive model and the observed heat flow. On the other hand, the dispersion of heat flow values is clearly related to the effect of hydrothermal circulation and can be used instead as a relative indicator of its magnitude (figure 4a). For instance, the integration of one standard deviation provides a first estimate $(12.8 \mathrm{TW})$, which can be corrected for the natural variability $\left(15 \mathrm{mWm}^{-2}\right.$ in the oldest part of the oceanic domain, see figure $\left.4 \mathrm{a}\right)$ and give a cumulative estimate $\sim 9 \mathrm{TW}$ (figure $4 \mathrm{~b}$ ). An other and more quantitative way is to extrapolate results of local studies (Villinger et al., 2002; Fisher, Davis, et al., 2003; Fisher, Stein, et al., 2003; Lucazeau et al., 2006; Fisher \& Wheat, 2010; Le Gal et al., 2018), which show that the presence of permeable basalt exposures or alternatively of a continuous impermeable sediment blanket are the main factors driving hydrothermal circulation. Therefore, the local relief of the seafloor can show if the surface is smooth and covered by impermeable sediment, or is rough and exposed to fluid circulation. Le Gal et al. (2018) used variogram techniques to estimate the local relief and showed that hydrothermal circulation effect reaches a maximum level of $60 \%$ of the surface heat flow for a local relief exceeding $150 \mathrm{~m}$. Variogram is hard to use at global scale as it is expensive in computer time, but other estimators like the ruggedness index (Riley et al., 1999) can be used more easily. Although the local relief was not determined in the same way, I used the relationship given by Le Gal et al. (2018) relating the fraction of conductive heat flow observed at the surface to the ruggedness. This method provides very similar results as the standard deviation method (figure $4 \mathrm{~b}$ ), showing a larger range of ages (0-130 Ma) affected by hydrothermal circulation than proposed by Stein and Stein (1992) and more consistent with observations of hydrothermal circulation on old seafloor (Von Herzen, 2004). The previous estimates (Stein \& Stein, 1994; Spinelli \& Harris, 2011) were not surprisingly far different from this one: they are mostly affected by an offset of $1.7 \mathrm{TW}$ that corresponds to the hydrothermal heat loss for age older than $65 \mathrm{Ma}$ (figure 4), which increases the hydrothermal heat loss to $\sim 10.5 \mathrm{TW}$.

\subsection{Continental heat flow}

The NGHF database contains 51621 continental data, more densely distributed in North America (17885 from USA and 2985 from Canada). The range of values varies from -52 to $15600 \mathrm{mWm}^{-2}$, with an arithmetic average $\mathrm{HFa}=68.1 \pm 51.1$ $\mathrm{mWm}^{-2}$, a median $\mathrm{HFm}=62.8 \mathrm{mWm}^{-2}$ and a surface weighted average $\mathrm{HFw}=$ $68.0 \mathrm{mWm}^{-2}$. These statistics are not very different from those obtained by Pollack et al. (1993) (table 1). 13139 of these measurements were obtained in vertical boreholes at thermal equilibrium, 18207 are derived from oil exploration wells and 14839 


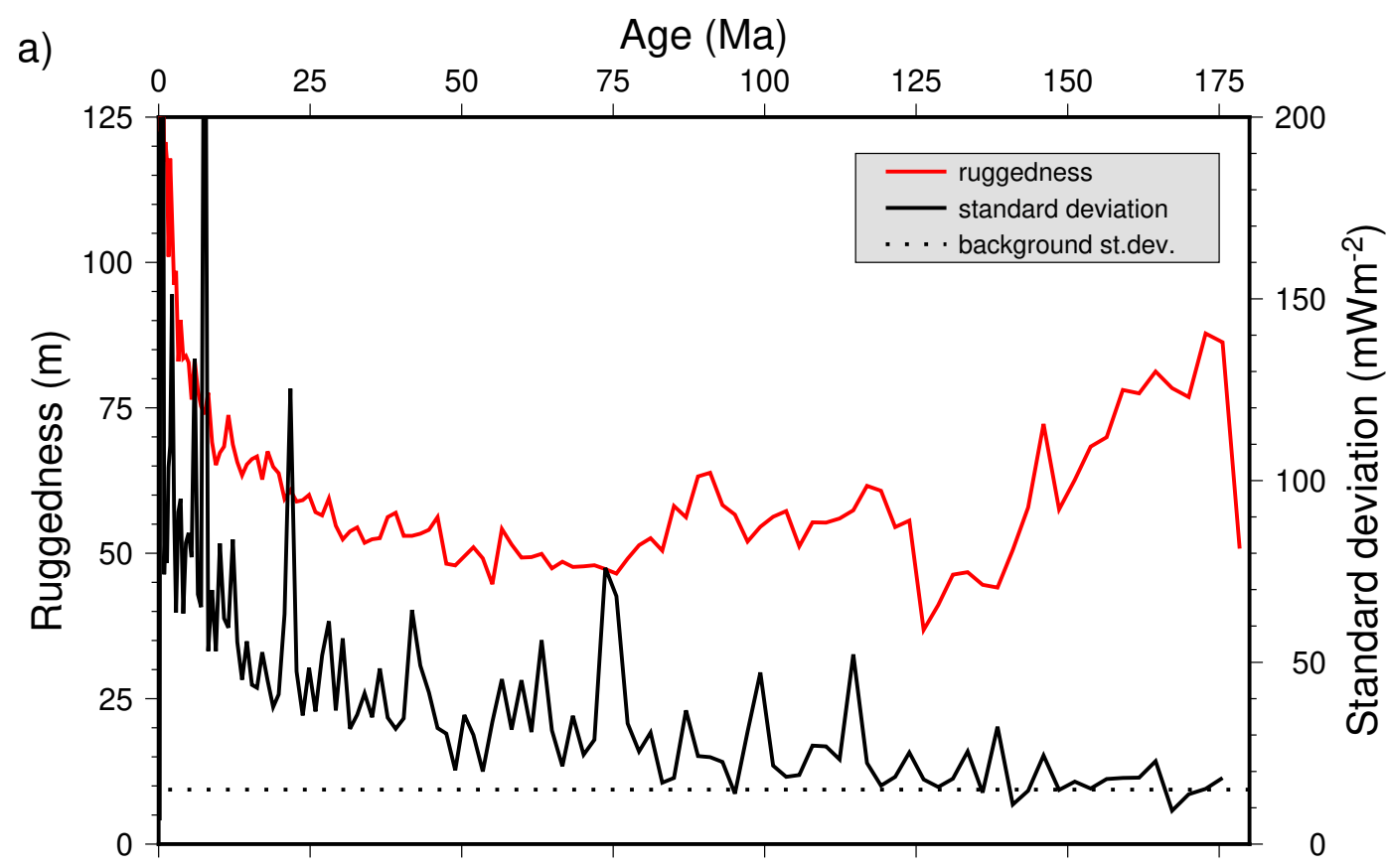

b)

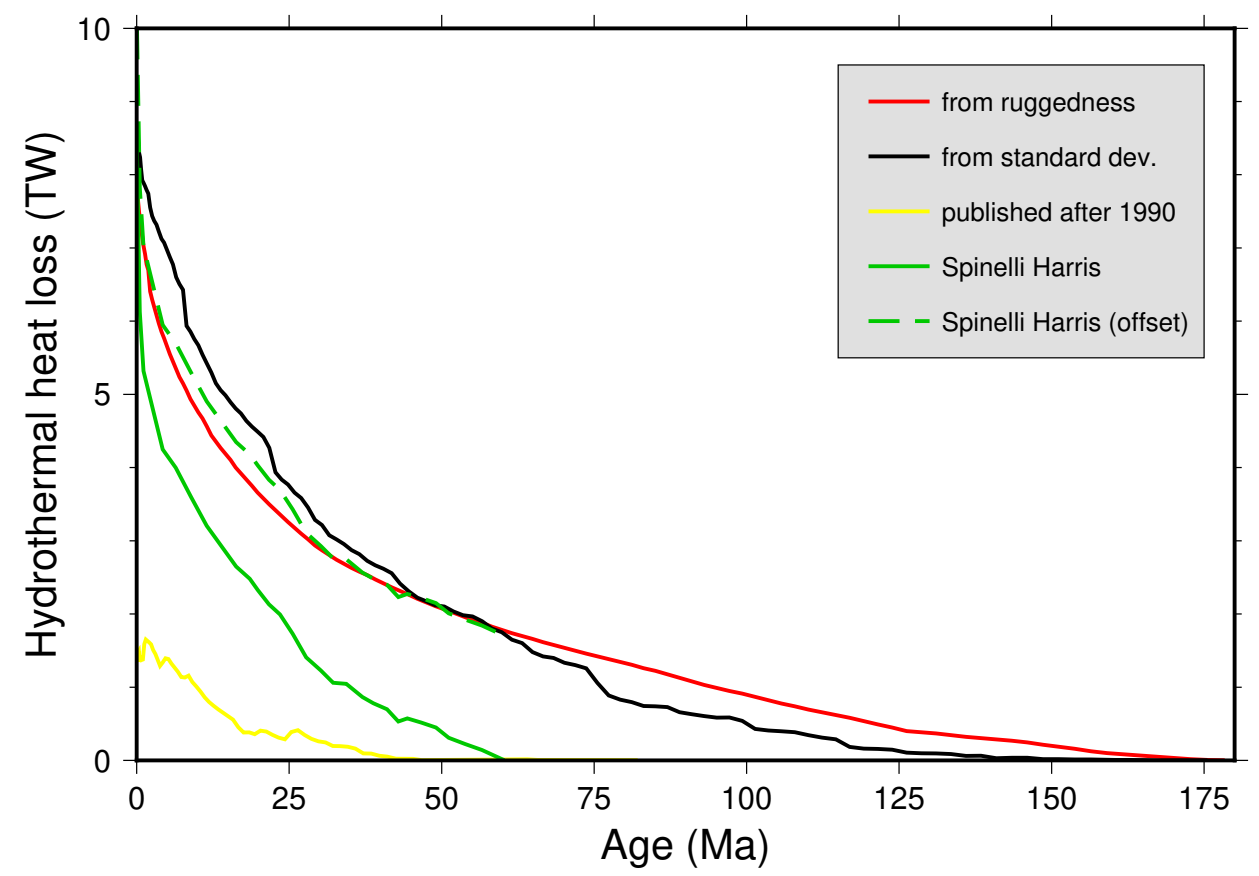

Figure 4. a) Average ruggedness and standard deviation $(1 \sigma)$ associated with observed heat flow measurements. The dotted line $\left(15 \mathrm{mWm}^{-2}\right.$ is considered as the natural variability of heat flow in absence of hydrothermal circulation. b) Cumulative hydrothermal heat loss with respect to model 2 (see figure 2). The red line represents the cumulative perturbation according to an empirical relationship from local studies (Le Gal et al., 2018), which relates the fraction of conductive heat flow $\frac{Q}{Q_{0}}$ to the local relief $S: \frac{Q}{Q_{0}}=3.8792 S^{-0.4}$. The black line corresponds to an estimate of the hydrothermal heat flux based on the standard deviation. The yellow line is the difference between model 2 and measurements published after 1990. The green line is the Spinelli and Harris (2011) estimate and the green dash line is the same estimate offset by 1.7 TW, which corresponds to the hydrothermal heat loss for ages $>65$ Ma. 
from marine techniques in lakes or continental margins. The origin of others measurements is not specified in the dataset. Average heat flow from oil wells measurements $\left(65 \pm 27 \mathrm{mWm}^{-2}\right)$ is not statistically different from that obtained in boreholes at thermal equilibrium $\left(62 \pm 32 \mathrm{mWm}^{-2}\right)$. There is also no important variation of the average heat flow between the main continental landmasses outside of the volcanic and geothermal areas, except Russia which has a lower value. Antarctica and Greenland are also different, but the differences are less significant because of the small number of measurements and the non representative areas covered by these measurements.

Several authors suggested that the continental heat flow could vary with age of the lithosphere (Polyak \& Smirnov, 1968; Hamza \& Verma, 1969; Vitorello et al., 1980; Sclater et al., 1981), in a similar way as oceanic lithosphere. The age of continents is more difficult to define, as a superposition of thermal processes (rifting or thickening of the crust, magmatic intrusions, erosion, etc.) can occur in space and in time. The last tectonic event having affected the thermal regime of the continental lithosphere is usually considered in the cited studies. In the first studies (Polyak \& Smirnov, 1968; Hamza \& Verma, 1969), a limited number of regional data was used, which provided relatively good relationships. In the later studies (Vitorello et al., 1980; Sclater et al., 1981), a larger dispersion of heat flow appeared, but still was interpreted by these authors as some thermal relaxation of the lithosphere with a time scale of $\sim 0.5 \mathrm{Ga}$. Sclater et al. (1981) suggested a constant average heat flow of $46 \mathrm{mWm}^{-2}$ for Precambrian, increasing to $77 \mathrm{mWm}^{-2}$ at the end of Proterozoic. Vitorello et al. (1980) interpreted the heat flow / age relationship as the superposition of a background heat flow $\left(\sim 27 \mathrm{mWm}^{-2}\right)$ at the base of an enriched radioactive upper crust, a radiogenic crustal component that would represent $40 \%$ of the surface heat flow and a transient component with a time scale of $\sim 500 \mathrm{Ma}$.

However, Rao et al. (1982) challenged the physical and statistical relevance of the heat flow / age relationship, arguing that, unlike oceanic lithosphere, no common process affects the thermal regime of the continental lithosphere and that other factors such as variations of the radiogenic content in the upper crust have much more effect than the age on the surface heat flow. It became evident later that the variations of surface heat flow in stable areas are mostly related to the variations of upper crustal heat production (Jaupart et al., 2014). As the number of continental measurements has significantly increased since these analysis, I examined again the continental heat flow / age relationship. Instead of using stratigraphy as in table 1, I defined the tectono thermal age from the USGS (1997) map, which distinguishes six categories: Archean (>2500 Ma), early Proterozoic (1600-2500 Ma), middle Proterozoic (900-1600 $\mathrm{Ma})$, late Proterozoic (570-900 Ma), Paleozoic (245-570 Ma) and Mesozoic-Cenozoic (0-245 Ma). I also subdivided continental surface into homogeneous units (e.g. Baltic shield, Williston basin, Sino-Korean craton...) and plotted them in several groups corresponding to the main landmasses (e.g. Europe, Africa, Central Asia...) in figure 5, where some previous interpretations (Vitorello et al., 1980; Sclater et al., 1981) are also shown. It appears clearly that the dispersion of heat flow values is important whatever the age and is more important than previously estimated. This dispersion may be related to the inaccurate age domains of the USGS (1997) map (e.g. part of the Tertiary basin Aaiun-Tarfaya in Western Africa is located in Archean) or to the variable radiogenic contribution of the upper crust, such as the Precambrian regions of Aravalli and Singbhum in India (Roy \& Rao, 2000), Slave in Canada (Perry et al., 2006) or South central Australia (Neumann et al., 2000). In order to avoid influence of uncertain age estimates, I cross checked the USGS (1997) tectono-thermal age map with the UNESCO stratigraphic map (CCGM/CGMW, 2000) and plot data belonging to the same era in both maps (figure 5): dispersion was significantly reduced for Archean, but remains important for Proterozoic and Paleozoic, as previously mentioned by Rao et al. (1982). Therefore, extrapolation of the continental heat flow based on the stratigraphic age (Davies \& Davies, 2010) or the last tectono thermal age (Chapman 


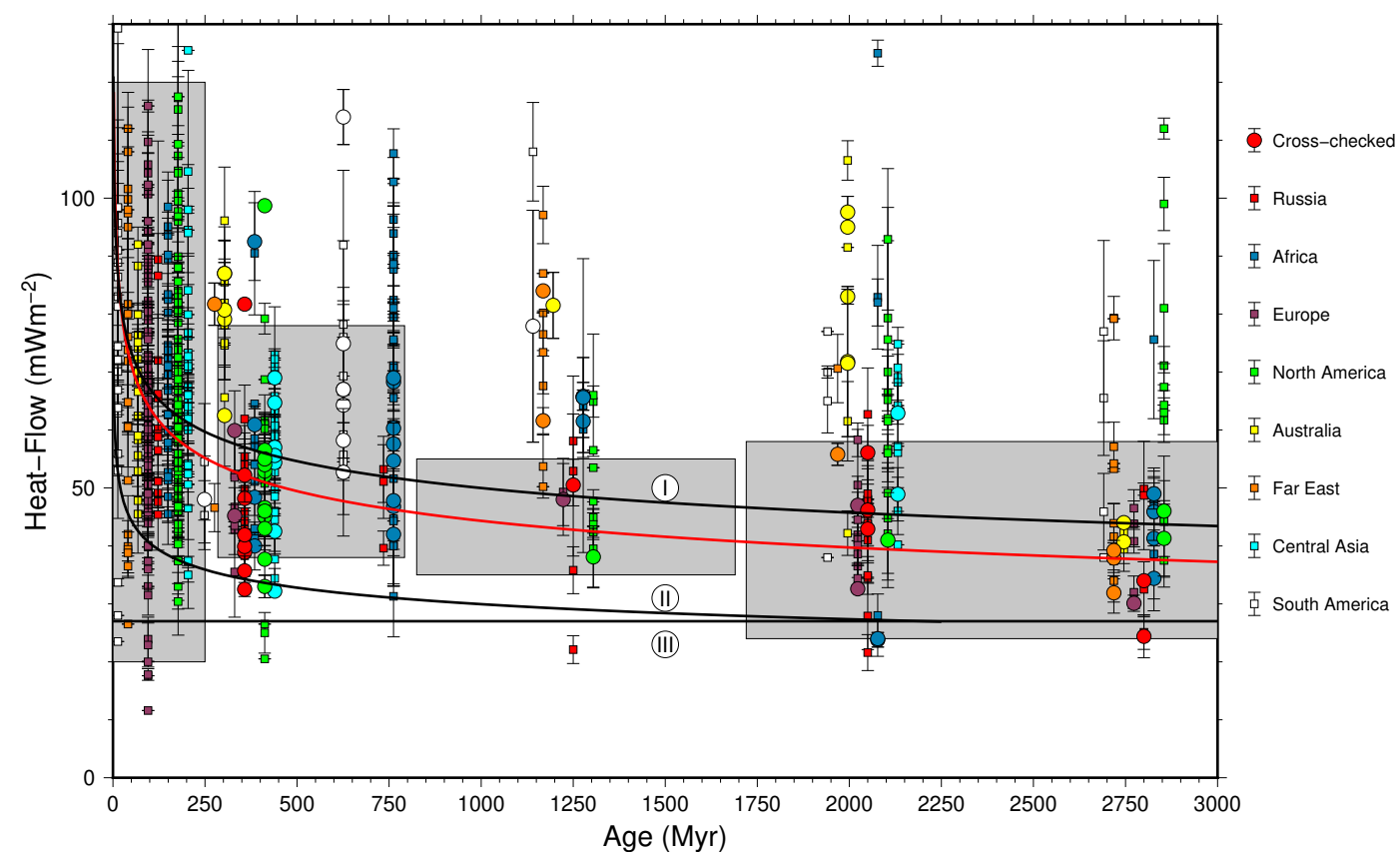

Figure 5. Continental heat flow vs last tectono thermal age. Heat flow is averaged for homogeneous geological units and according to the tectono thermal ages from a USGS map. Tectonothermal age is divided in six categories: Archean (>2500 Ma), early Proterozoic (1600$2500 \mathrm{Ma}$ ), middle Proterozoic (900-1600 Ma), late Proterozoic (570-900 Ma), Paleozoic (245-570 $\mathrm{Ma})$ and Mesozoic-Cenozoic (0-245 Ma). For each of them, heat flow / age is displayed at the middle of the age interval with a color symbol corresponding to a specific landmass and eventually offset laterally for clarity (Russia is on the central position). The small square symbols are locations where the tectono-thermal age from USGS map is not consistent with the stratigraphic age (CCGM/CGMW, 2000). The larger circle symbols are conversely locations where they are similar. The red line corresponds to the best fit power law relationship : $H F=132 /$ Age $^{0.158}$ for the Russian landmass. Grey boxes correspond to heat flow age domains defined by Sclater et al. (1981). Black lines correspond to the trends proposed by (Vitorello et al., 1980): (I) is surface heat flow, (II) is the reduced heat flow (surface heat flow minus upper crust radiogenic contribution) that includes a transient component and (III) is background heat flow $\sim 27 \mathrm{mWm}^{-2}$ that includes $\sim 12 \mathrm{mWm}^{-2}$ mantle heat flow and $\sim 15 \mathrm{mWm}^{-2}$ lower crust radiogenic contribution. 
\& Pollack, 1975) may have limited utility as noted by the authors, and I will discuss a method to improve mapping in the next part of this paper.

In contrast to continents, divergent continental margins have a well defined thermal origin (rifting or break-up, magmatism,...) and a less important radiogenic contribution related to crustal thinning. Therefore, heat flow could be more likely linked to age in these specific domains. As the age of continental break-up is hard to obtain for all locations, the age of the closest oceanic domain was used systematically, except for Red Sea where it is not defined in the Müller et al. (2008) data.

Heat flow, corrected systematically for sedimentation effects with global datasets (Divins, 2003; Whittaker et al., 2013), was selected only in the deep continental domains of the margin including the Ocean Continent Transition (OCT), and was averaged by basin and country domains. The resulting relationship between heat flow and age (figure 6) is fairly compatible with an oceanic type conductive cooling. This suggests that continental margins evolve toward a different state after thermal relaxation than before rifting, when the mantle heat flow had a lower value. This could be an important aspect to consider when modelling petroleum systems.

Heat flow in other types of continental margins is not as simply related to the age. In transform margins, age is more difficult to define and the age of the closest oceanic domain is probably not relevant. Convergent margins are also more complex as the age cannot be simply defined as the age of the subducting plate. Consequently, the relation between heat flow and age cannot be established clearly for these types of continental margins.

\section{Prediction of heat flow using a similarity method}

Most of the previous studies (Chapman \& Pollack, 1975; Sclater et al., 1980; Vitorello \& Pollack, 1980; Sclater et al., 1981; Pollack et al., 1993; Davies \& Davies, 2010; Davies, 2013; Jaupart et al., 2015) have used age or tectono-thermal age to extrapolate heat flow where no data exists. Other studies related surface heat flow to temperature proxies in the lithosphere, such as the upper mantle shear-wave velocities (Shapiro \& Ritzwoller, 2004) or the Curie point depth (Artemieva, 2006; Li et al., 2017). As all of these approaches capture only part of the processes affecting surface heat flow, Goutorbe et al. (2011) suggested to stack these different proxies in order to get redundant information better constraining the heat flow predictions. They tested different methods of extrapolation and found that the similarity method was optimal, both in terms of prediction ability and computation time. The method is based on the evaluation, at each location of a grid $\left(0.5^{\circ} \times 0.5^{\circ}\right.$ in the present study), of the number of similarities $N_{\text {sim }}$ with several heat flow proxies (observables) at all other locations of the grid where surface heat flow is known. Two cells are similar if they belong to the same class (e.g. Paleozoic), the same range (e.g. elevation between 1000 and $1200 \mathrm{~m}$ ) or the same class of distance to a specific geological feature below a threshold value (e.g. less than $500 \mathrm{~km}$ to a subduction). Each additional similarity increases the weight $w_{i}$ in the collection of heat flows by a factor $K$, which optimal value was estimated to $\simeq 10$ by Goutorbe et al. (2011):

$$
w_{i}=K^{N_{s i m}}
$$

Classical statistics (mean $\bar{Q}$ and standard deviation $\sigma_{Q}$ ) provide estimates of the average value $\bar{Q}$ and its uncertainty $\sigma_{Q}$ from the collection of heat flow:

$$
\bar{Q}=\frac{\sum_{i} w_{i} Q_{i}}{\sum_{i} w_{i}}
$$




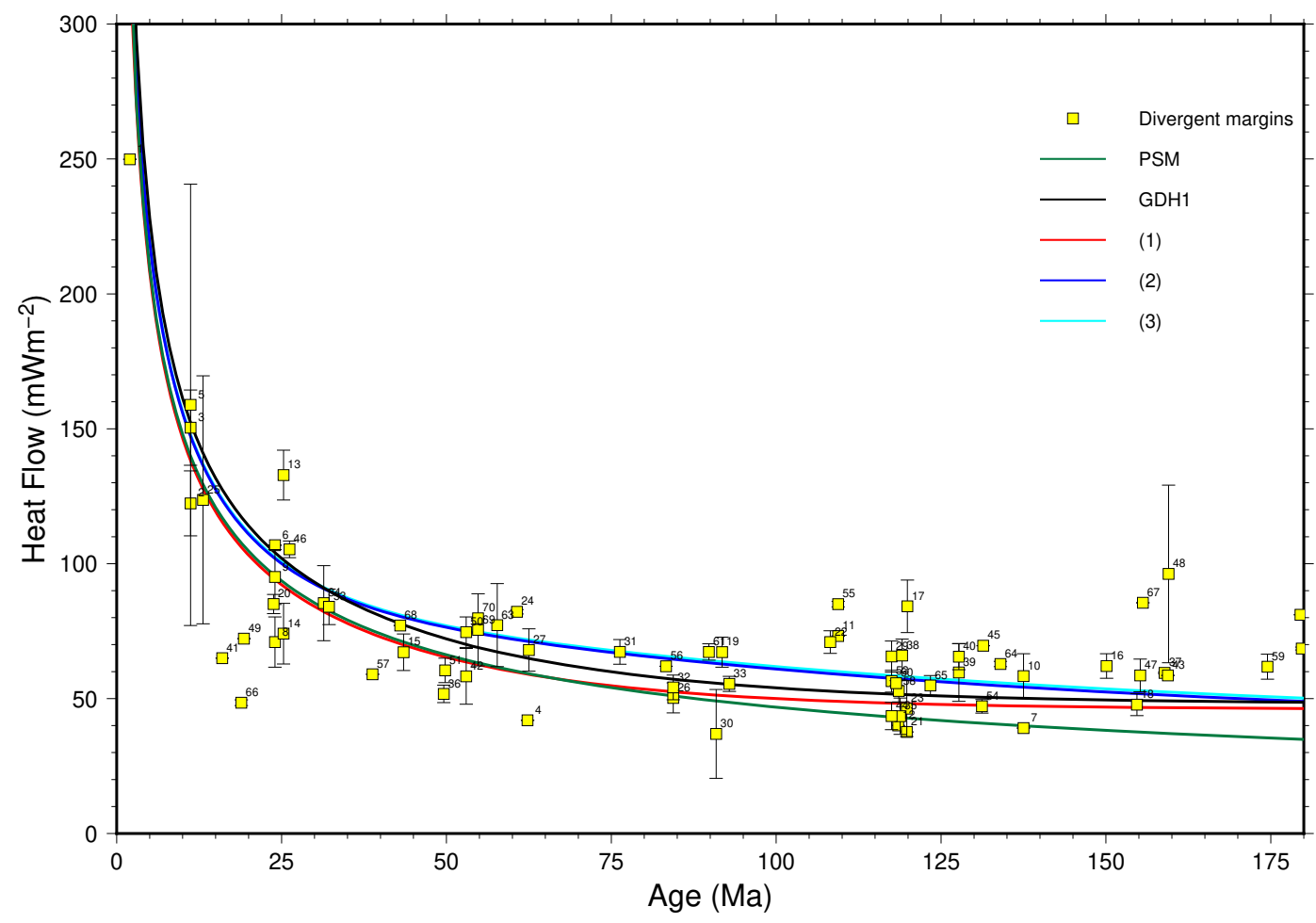

Figure 6. Heat flow vs age on divergent continental margins (red squares = active margins; blue squares $=$ passive margins). Lines correspond to oceanic models described in figure 2. Heat flow is averaged for country subsets defined by numbers: 1- Red Sea Basin (Ethiopia ), 2- Red Sea Basin (Eritrea ), 3- Red Sea Basin (Egypt ), 4- Burgas Basin (Bulgaria), 5- Central Red Sea Rift System (Egypt), 6- Djefara Basin (Libya), 7- Guadalquivir Basin (Portugal), 8- Gulf of Suez Basin (Egypt), 9- Pelagian Basin (Italy), 10- Rharb-Prerif Basin (Portugal), 11- Amazon Cone (Brazil), 12- Angola Basin (Angola), 13- Balingian Province (Malaysia), 14- Baram Delta (Brunei), 15- Bass Basin (Australia), 16- Browse Basin (Australia), 17- Campos Basin (Brazil), 18- Canning Basin (Australia), 19- Cantabrian Zone (Spain), 20- Catalano-Balearic Basin (Spain), 21- Cauvery Basin (India), 22- Celtic Sea Graben System (United Kingdom), 23Congo Fan (Angola), 24- Djefara Basin (Tunisia), 25- East Greenland Basin (Greenland), 26East Newfoundland Basin (Canada), 27- East Siberian Sea Basin (Russia), 28- Essaouira Basin (Morocco), 29- Gabon Coastal Basin (Gabon), 30- Galician Basin (Spain), 31- Gippsland Basin (Australia), 32- Grand Banks Basin (Canada), 33- Great Australian Bight (Australia), 34- Gulf of Aden (Oman), 35- Kwanza Basin (Angola), 36- Labrador Shelf (Canada), 37- Lamu Embayment (Somalia), 38- Lower Congo Basin (Gabon), 39- Lusitanian Basin (Portugal), 40- Mackenzie Delta (Canada), 41- Money Shoal Basin (Australia), 42- More Basin (Norway), 43- Mozambique Basin (Mozambique), 44- Namibe Basin (Angola), 45- Natal Trough (South Africa), 46- North Balearic-Ligurian Basin (Spain), 47- North Carnarvon Basin (Australia), 48- North Chukchi Basin (Russia), 49- Northwest Sabah Province (Philippines), 50- Norwegian-Danish Basin (Denmark), 51- Otway Basin (Australia), 52- Outeniqua Basin (South Africa), 53- Pearl River Mouth (Zhujiangkou) Basin (Taiwan), 54- Perth Basin (Australia), 55- Potiguar Basin (Brazil), 56Rockall Trough (Ireland), 57- Sagaleh Basin (Somalia), 58- Santos Basin (Brazil), 59- Senegal Basin (Senegal), 60- Sergipe-Alagoas Basin (Brazil), 61- Sirte Basin (Libya), 62- Souss Trough (Morocco), 63- South Barents Sea Basin (Russia), 64- South Carnarvon Basin (Australia), 65Southwest African Coastal Basin (Namibia), 66- Southwest Palawan Basin (Philippines), 67- Tanzania Coastal Basin (Tanzania), 68- Troms-Finnmark Fault Complex (Norway), 69- Voring Basin (Norway), 70- Voring Plateau (Norway). 


$$
\sigma_{Q}=\sqrt{\frac{\left.\sum w_{i}\left(Q_{i}-\bar{Q}\right)^{2}\right)}{\sum w_{i}}}
$$

An example of collection of heat flow at some location of the grid is given in figure S9 of the supporting information. More details on the method can be found in Goutorbe et al. (2011). The method was also briefly discussed in Sclater et al. (2014).

The method was used here with NGHF, and I proceeded in several steps to explore how increasing number of observables changes the distribution of heat flow at the Earth surface. The predictability of the similarity method depends strongly on the number and on the quality of observables. The greater the number of observables, the smaller the misfit between measurements $q_{o b s}$ and predicted heat flow $q_{\text {pred }}$ :

$$
\text { misfit }=\sqrt{\frac{\sum\left(q_{o b s}-q_{p r e d}\right)^{2}}{N_{o b s}}}
$$

The misfit varies from $\simeq 90 \mathrm{mWm}^{-2}$ for 1 observable to $\simeq 4 \mathrm{mWm}^{-2}$ for 50 observables. The combination of different observables affects the convergence of the process (Figure 7). In this figure, I show two examples that behave differently: the first set was optimized for a faster convergence, while the second set was chosen randomly. The first set evolves more or less as a function of $1 / \mathrm{N}$ (Figure 7 ), and after a rapid decrease of the RMS, there is no significant improvement when more observables are added. There is no systematic effect of one specific observable, as it can have a significant influence with some combination and no influence with another one. Therefore, the optimal combination was obtained by tries and errors.

A great number of observables can produce artifacts where no heat flow measurement exists, especially if the quality of these observables is not good. Therefore, there is a trade-off between an acceptable misfit and a more likely predictability. For the specific sets used in this study, the best models are obtained accordingly for 14 observables (first set) and 19 observables (second set), assuming an acceptable RMS less than $6 \mathrm{mWm}^{-2}$ (figure 7). The 14 observables used for the first set are displayed with their direct surface heat flow prediction in figures of the supporting information.

I also provide statistics (table 3) comparing usual extrapolation from heat flow measurements only, with values predicted by the similarity method. As shown previously, oceanic heat flow measurements were improved in the $90 \mathrm{~s}$ and therefore I selected only measurements published after 1990. I also included geothermal and volcanic areas in the averaged values, which differs from the statistics in the first section of this paper. The differences between results of table 1 and 3 are therefore related to a slightly different processing of the data. Where several measurements exist within a specific cell of the grid, the arithmetic average was given to this cell: all cells with heat flow measurements are explored to determine if similarities exist with other cells with no measurements. The number of oceanic cells covered by measurements is 1672 (only data after 1990) and the number of continental cells 10914. Heat flow values for these cells range between -6 and $2777 \mathrm{mWm}^{-2}$, with an average of $89 \pm 128 \mathrm{mWm}^{-2}$ in the oceanic domain and $67 \pm 31 \mathrm{mWm}^{-2}$ for continents. The global heat loss estimated only from measurements is $40.8 \mathrm{TW}$ (26.7 TW for oceans and $14.1 \mathrm{TW}$ for continents).

Four predictions are discussed here (table 3 and figure 8).

The first prediction is based on 2 observables, the age of the oceanic seafloor (Müller et al., 2008) and 12 tomographic classes defined by Goutorbe et al. (2011) from the shear wave velocity model of Shapiro and Ritzwoller (2002). As the possible number of corresponding classes between 2 cells is limited, the heat flow map (figure 


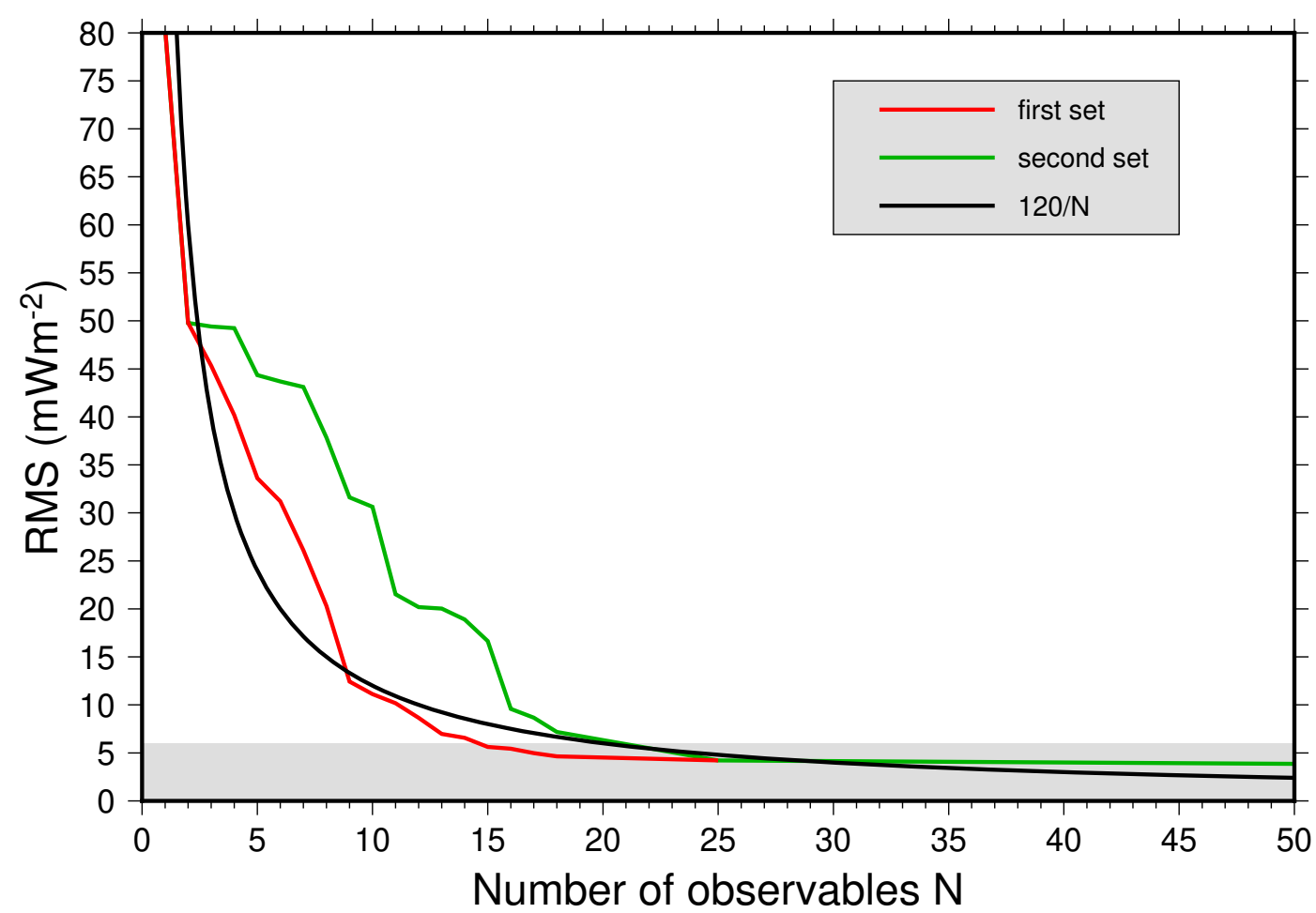

Figure 7. Evolution of the predictability (RMS) of the similarity method as a function of the number of observables. The grey area corresponds to RMS less than $6 \%$.

8a) shows smooth variations and the misfit between predicted and measured heat flow $\left(50 \mathrm{mWm}^{-2}\right)$ is the largest (table 3$)$.

The second prediction is based on 14 observables, including age (Müller et al., 2008; CCGM/CGMW, 2000), seismic tomography (Shapiro \& Ritzwoller, 2002), lithospheric thickness (Conrad \& Lithgow-Bertelloni, 2006), Curie point depth (Li et al., 2017), free air anomalies (Sandwell \& Smith, 2009), topography (Kautz, 2017) and distance to several tectonic features (rifts, orogens, active seismic zones, volcanic zones, Archean cores). All of them, and their potential effect on predicted heat flow, are displayed in figure S10 to S23 of the supporting information. The heat flow map (figure $8 \mathrm{~b}$ ) shows a better resolution than with 2 observables, revealing smaller scale anomalies. The misfit between observed and predicted heat flow is noticeably reduced to 7 $\mathrm{mWm}^{-2}$ (table 3 ).

Other predictions (25 and 50 observables) are not significantly improved (misfit is 7 and $4 \mathrm{mWm}^{-2}$ ), and increase the risk of generating noise elsewhere. For instance, the predicted heat flow map with 50 observables (figure 8c) shows a large variability in regions with no measurements such as off-axis oceanic domains. On the other hand, this could also suggest locations for new investigations.

A test of the prediction capability of the method was also made on Africa. All the terrestrial heat flow measurements in Africa were removed before the test and compared to the results obtained with these measurements included. In both cases, 14 observables (preferred prediction) were used. The resulting statistical differences between the two prediction are insignificant $\left(64.6 \pm 17.2 \mathrm{mWm}^{-2}\right.$ for the reference and $65.1 \pm 15.9 \mathrm{~mW} \mathrm{~m}^{-2}$ for the test). The maps of African heat flow (figure 9) show some differences in a few specific regions, like the Saharian basins (Tindouf, Illizi, Ahnet, ...) 
(a)

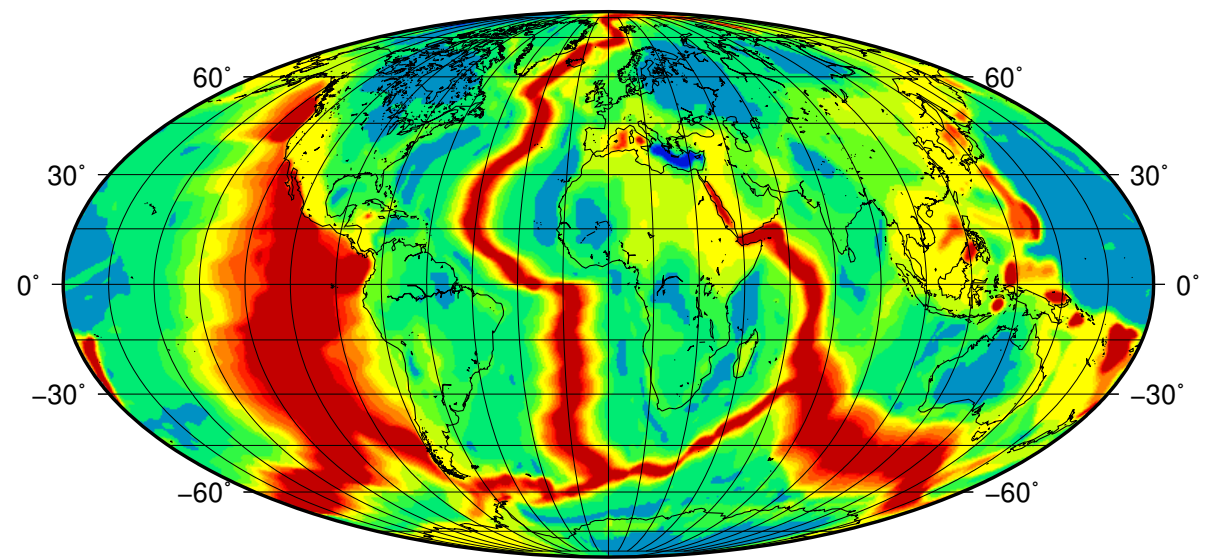

(b)

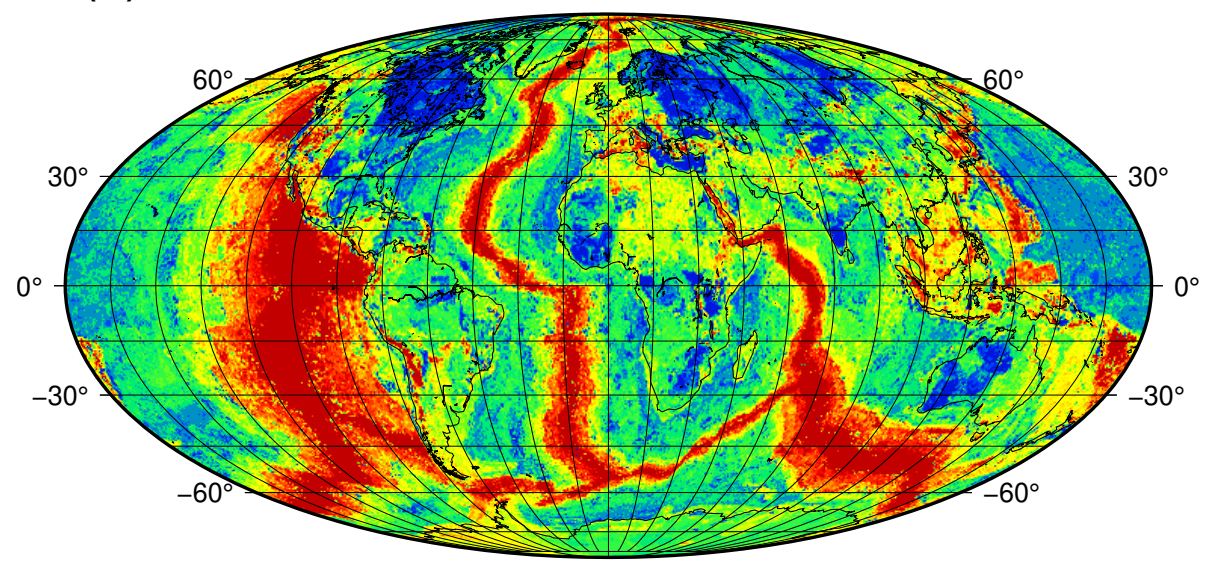

(c)

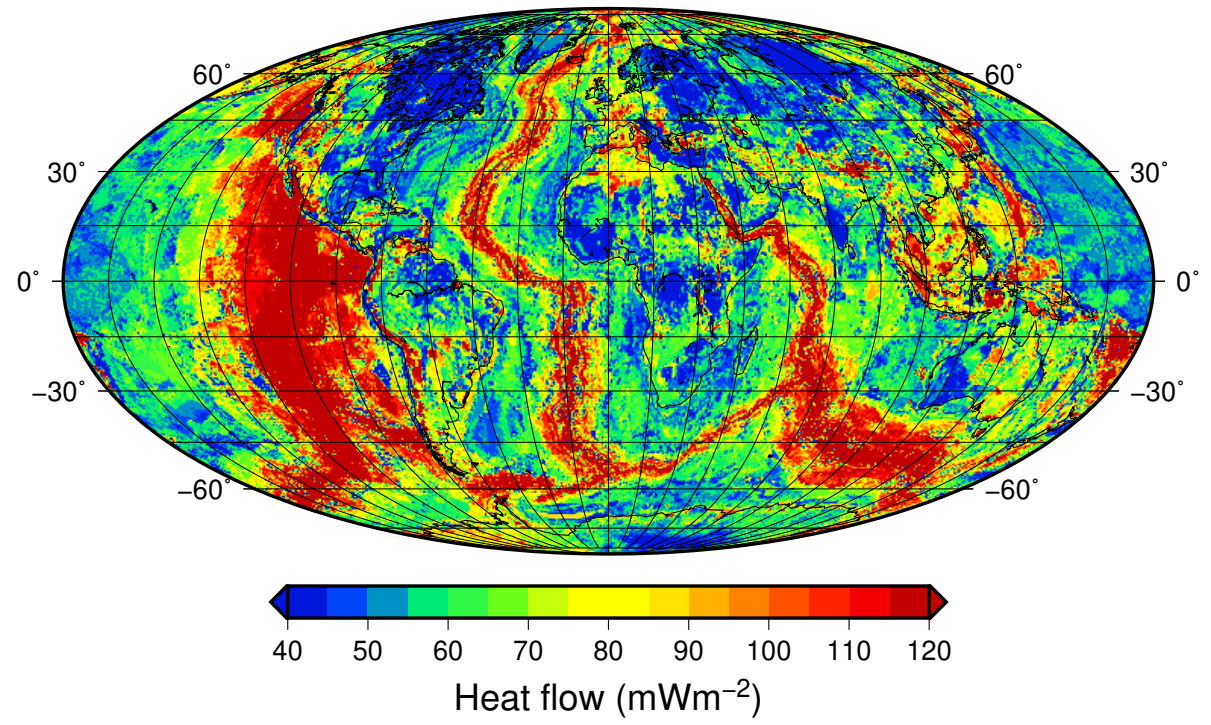

Figure 8. Global heat flow map based on similarities with (a) 2 observables; (b) 14 observables (preferred prediction); (c) 50 observables. 
or the East African rift in Ethiopia where the high heat flow anomaly is not predicted without the heat flow measurements constraints. However, most of the large scale features of the reference are described satisfactorily in the test.

A comparison of statistical averages for stratigraphic or geographic subsets (table 3 ) shows that the average of predicted values is generally in agreement with the average of observed values. There are a few exceptions, mostly for the young seafloor (0-5 Ma) and some geographic subsets (Central America, Greenland, Antarctica) where there exist few and non representative measurements. Large numbers of observables increase the variability of oceanic heat flow near the ridge axis, which, for instance, becomes larger than measurements in the range 1.6-5.3 Ma of seafloor ages from 1.6-5.3 Ma.

The predicted heat flow is stable with the number of observables for continents, while it increases for the oceans, mostly in the range 0-1.6 Ma where the variability of hydrothermal circulation is the most important. The total heat loss predicted with 14 observables is similar to that extrapolated from heat flow measurements, and increases with a larger number of observables as a consequence of the oceanic heat flow increase in the range 0-1.6 Ma.

In map view, the predicted heat flow (figure 8) outlines some remarkable trends.

In oceanic domains, map calculated with the largest numbers of observables shows large heterogenities. This is especially important for the Mid Atlantic Ridge and the South East Indian ridge. This is of course not prescribed but related to the dispersion of values caused by hydrothermal circulation and propagated to similar locations.

The divergent continental margins are clearly marked by a higher heat flow than their adjacent ocean and continent. This anomaly is particularly well developed on the Atlantic margins (Brazil, Africa) and interestingly on the Antarctica margins (figure 8c) well constrained by measurements (Nagao et al., 2002; Morin et al., 2010). Several studies have attributed the anomaly on mature continental margins to an edge driven convection caused by lateral temperature and rheology contrast at the interface of oceanic and continental lithospheres (King \& Anderson, 1998; Lucazeau et al., 2004; Hardebol et al., 2012).

In continental domains, North America, Europe and Russia are characterized by large zones of low heat flow associated with shields, while in South America, Africa and Australia, these zones are more fragmented. In Antarctica, a similar large domain of low heat flow $\left(40-50 \mathrm{mWm}^{-2}\right)$ is predicted with 50 observables in the central eastern part (figure 8c), as previously suggested by other authors (Shapiro \& Ritzwoller, 2004; Liefferinge \& Pattyn, 2013) but is weaker with 14 observables. In Greenland, some new heat flow data and the occurrence of thermal springs were associated to a heat flow anomaly the east-northeast area (Rogozhina et al., 2016; Rysgaard et al., 2018), but the similarity method contains observables that hardly support the existence of this anomaly, which appears only with 50 observables. In Central and South America, the predicted heat flow is much higher than the extrapolation of heat flow measured in this area. This is related to the presence of volcanic and back arcs, which correspond generally to high heat flow like in the Andes or Cascade range in North America. Far East margins are also associated with high heat flow of similar origin.

\section{Conclusions}

The objective of this paper was to reexamine the main trends of heat flow at the Earth surface with a significantly upgraded database. An important result is that the previous studies were statistically robust, and the previous estimates of the global heat budget are not strongly modified. However, new oceanic heat flow measurements are 
$\neg$ ت

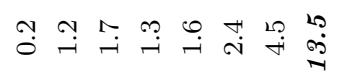

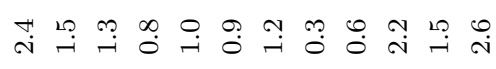

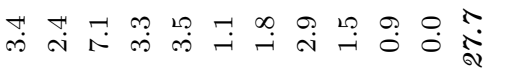

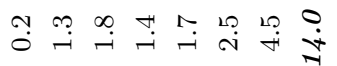

น゚ำ

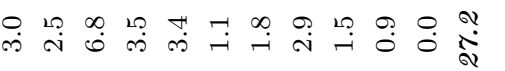

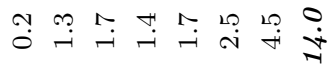

นึำำ

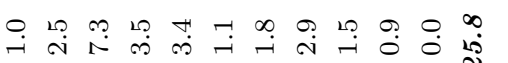

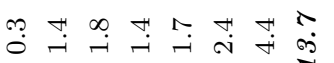

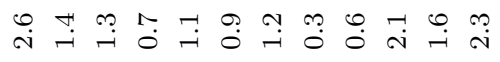

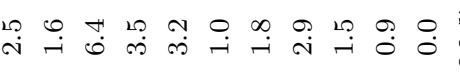

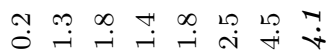

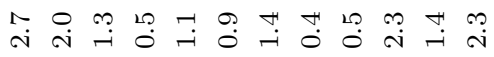

央品喿

H H H H H H H H H H H H

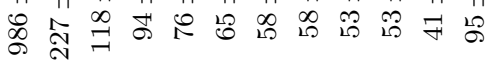

サี ๙

ล

$\mathrm{HH}+\mathrm{HHH} H+\mathrm{H} H$

$H+H+H H H+H+H H$

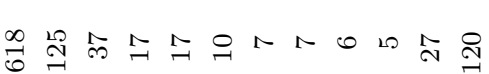

국

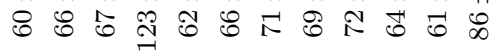

$H+H+H+H H H H H H H$

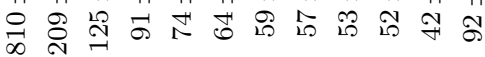

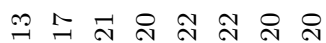

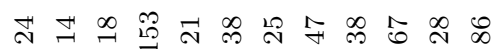

$\mathrm{H}+\mathrm{H}+\mathrm{H} H \mathrm{HH} H$

H H H H H H H H H H H H

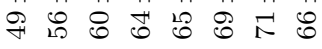

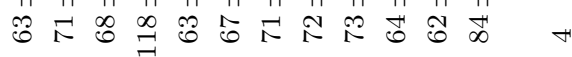

落

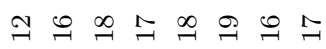

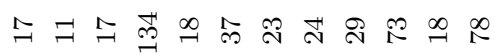

$H+H+H+H H H+H H H$

$\mathrm{H}+\mathrm{H} H \mathrm{HH} H \mathrm{H} H$

$H+H+H H H+H H H H H$

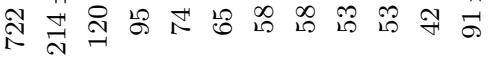

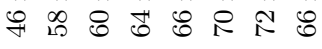

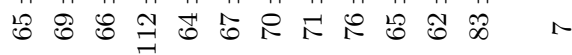

的药

$\wedge \infty \circ \rho \circ \sigma \rho ?$

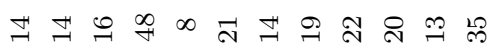

$H+H+H+H H H H H H H$

$H+H+H H H+H$

$H+H H H+H H H H H H$

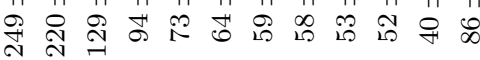

暨

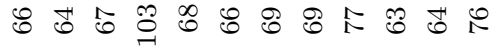

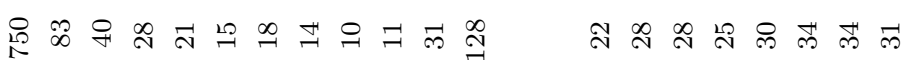

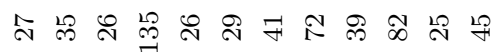

$H+H H H+H H H+H H$

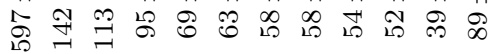

H H H H H H H H

$H+H H+H+H H H H H H$

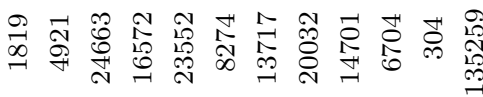

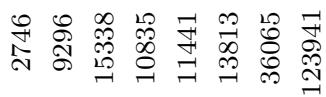

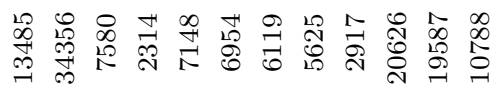

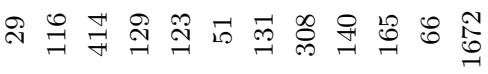

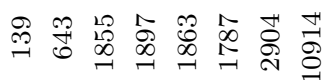

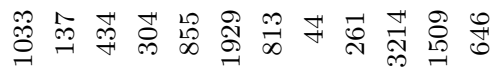

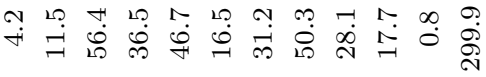

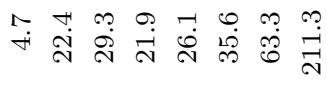

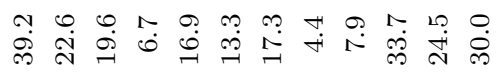

离离

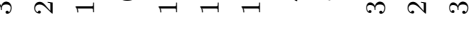

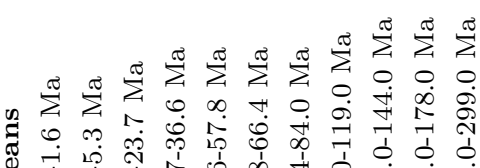

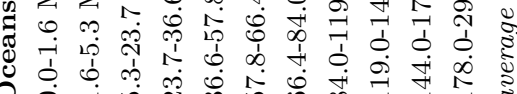

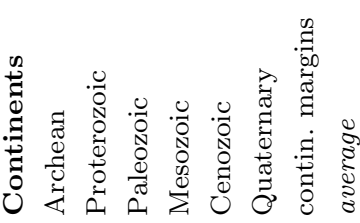

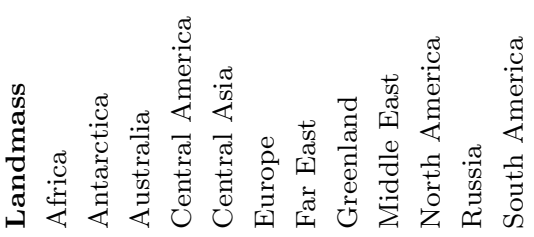

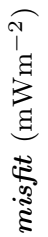




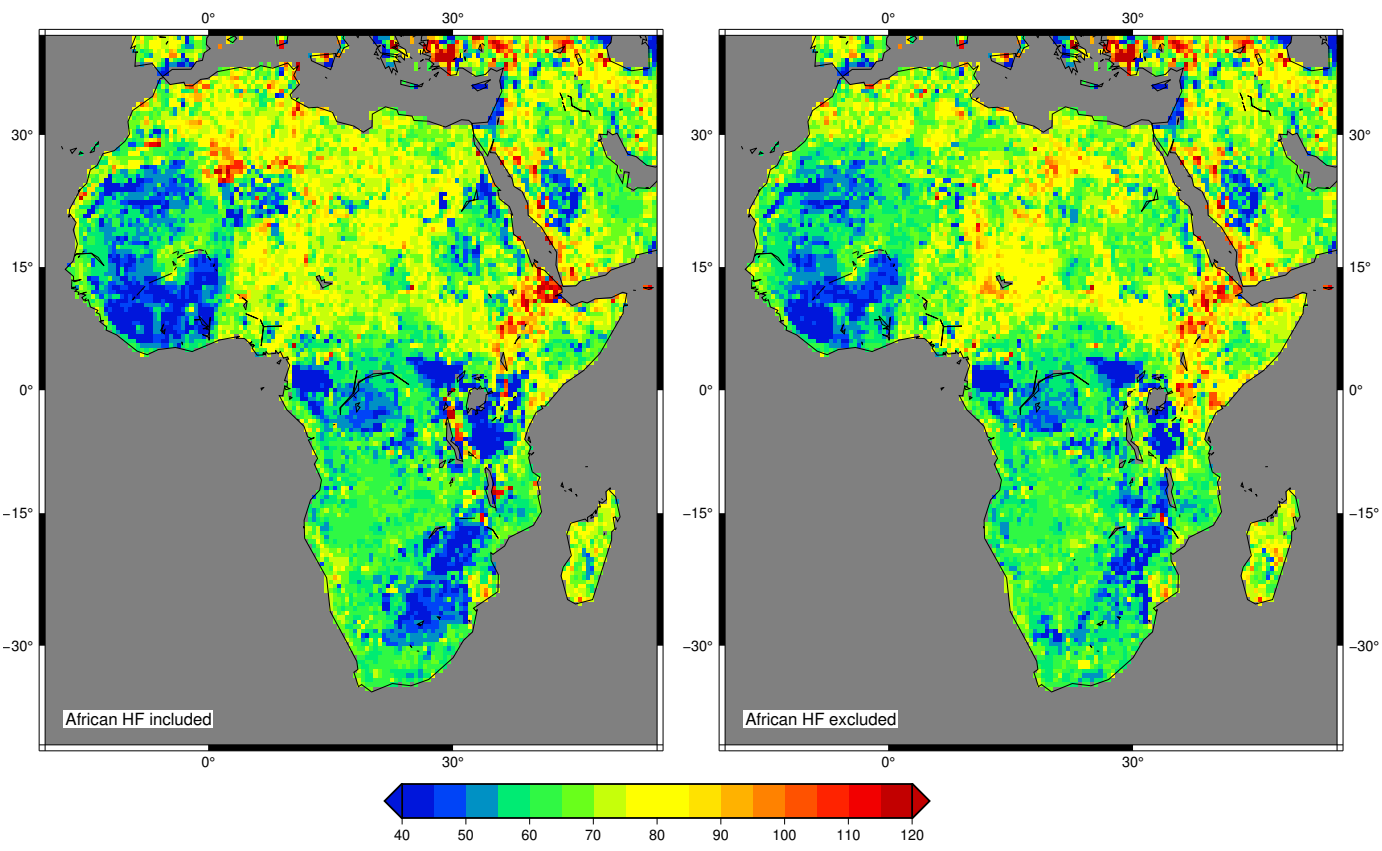

Figure 9. Comparison of heat flow predictions in Africa with (left part) or without (right part) heat flow measurements, and for 25 observables. The statistical differences for Africa are negligible $\left(64.6 \pm 17.2 \mathrm{mWm}^{-2}\right.$ and $65.1 \pm 15.9 \mathrm{mWm}^{-2}$ with and without African HF data), but few differences in northern Africa (Sahara) and east Africa (Tanzania, Somalia) are noticeable on the maps.

significantly different from previous ones because they often involve multi-penetration techniques or new techniques that allowed investigations in virgin domains like mid ocean ridges axis. The consequence is that the statistical difference with conductive cooling models decreases in average for age younger than $65 \mathrm{Ma}$, but with a dispersion that is still important or even larger than in the Stein and Stein (1992) study. As this difference can no longer be used to estimate hydrothermal heat flow, I suggested two alternative methods that lead to a supplementary contribution of $1.5 \mathrm{TW}$ accounting for the hydrothermal circulation effect in the old seafloor $(>65 \mathrm{Ma})$.

The seafloor subsidence derived from the global binning of bathymetry is not consistent with that obtained at heat flow sites only. The origin of this difference is related to an anomalous subsidence in regions of hot spots and large igneous provinces, causing a flattening at global scale, and where heat flow measurements are few. Therefore, at heat flow sites, previous cooling models cannot simultaneous explain subsidence and heat flow for old oceans. This problem has already been raised by Nagihara et al. (1996) who studied subsidence and heat flow for a selection of nine locations with a basement older than $100 \mathrm{Ma}$ and corrected for sediment and crustal thickness variations. The observed heat flow at these locations appeared higher than predicted by the PS model, which conversely agreed very well with subsidence. The authors interpreted this paradox by reheating of the old lithosphere related to a more likely occurence of thermal interactions with hot spots, but this should also affect subsidence. I suggest alternatively that this is the normal evolution of oceanic lithosphere for old age of the seafloor and explored if some model could explain the two sets of data simultaneously. The optimal model is obtained for a constant heat flow $\left(\sim 36.4 \mathrm{mWm}^{-2}\right)$ at the base of a $114 \mathrm{~km}$ thick lithosphere and a moderate potential temperature of the mantle $(\sim$ $1235{ }^{\circ} \mathrm{C}$ ). 
In continents, the heat flow cannot be statistically related to the last tectonothermal age or stratigraphic age as suggested frequently in past studies. There is a large variability that prevents any significant trend. Only Archean provinces $\left(46 \mathrm{mWm}^{-2}\right)$ are significantly lower and Quaternary domains significantly higher $\left(70 \mathrm{mWm}^{-2}\right)$ than other continental regions for ages spanning from early Proterozoic to Cenozoic (60$65 \mathrm{mWm}^{-2}$ ). On the other hand, divergent continental margins have a heat flow dependence on age of the continental break-up and behave more like an oceanic domain.

The variability of heat flow independently of the age is not a real problem for global energy estimates, but makes a good mapping of surface heat flow difficult. I used a multi-proxies approach to derive a new global map at the scale of $0.5^{\circ}$ square, which fairly reproduces the known local geological features and provides slightly modified statistics. For instance, Greenland and Antarctica would be notably cooler than existing heat flow measurements suggest. The number of observables decreases the misfit with observed heat flow, more or less as a function $1 / \mathrm{N}$ of the number of observables. The preferred prediction is obtained with 14 observables, for which RMS at heat flow locations is only $6 \%$. Heat flow anomalies are generated locally where no measurement exists. They could be real or artifacts, but could serve as potential targets for new studies. One especially interesting anomaly arising from this analysis is the quasi systematic higher heat flow surrounding continents that could attest of edge driven convection.

When observations only are considered, the global heat loss from this approach is $40.8 \mathrm{TW}$ (14.1 TW for continents and $26.7 \mathrm{TW}$ for oceans). By forcing oceanic heat flow with a conductive model fitting subsidence and heat flow, the total heat loss is 44 TW, similar to recent estimates (Davies \& Davies, 2010; Sclater et al., 2014; Jaupart et al., 2015). Oceanic hydrothermal heat loss would represent $10.5 \mathrm{TW}$, i.e. one fourth of the total value.

\section{Acronyms}

BSR Bottom Simulating Reflector

CHABLIS Constant Heat flow At the Base of the LIthoSphere

GDH1 Global Depth and Heat flow model (Stein \& Stein, 1992)

GLOBHEAT Global Heat Flow dataset published by Pollack et al. (1993)

GTOPO30 Global topography/bathymetry grid from a wide variety of data sources IHFC International Heat Flow Commission

NGHF New Global Heat Flow

PS Parsons and Sclater (1977) Model

\section{Acknowledgments}

All figures were drawn with GMT 5.4.5 (Wessel et al., 2013). The manuscript benefited from a first reading and discussions with Frédérique Rolandone and Valérie Vidal, and from constructive reviews by Derrick Hasterok, J. Huw Davies and John G. Sclater. Supporting information contains additional tables and figures, separate csv files including the NGHF dataset (NGHF.csv) in the same format as the previous GLOBHEAT file (Pollack et al., 1993) and the preferred heat flow prediction map (HFgrid14.csv). This is IPGP contribution \# 4051. 


\section{References}

Adam, C., \& Vidal, V. (2010). Mantle flow drives the subsidence of oceanic plates. Science, 328, 83-85. doi: 10.1126/science.1185906

Artemieva, I. M. (2006). Global $1^{\circ} \mathrm{x} 1^{\circ}$ thermal model TC1 for the continental lithosphere: Implications for lithosphere secular evolution. Tectonophysics, 416(14), 245-277. doi: 10.1016/j.tecto.2005.11.022

Balling, N., Haenel, R., Ungemach, P., Vasseur, G., \& Wheildon, J. (1981). Preliminary guidelines for heat flow density determination (Tech. Rep.). Commission of the European Communities.

Becker, K., Von Herzen, R. P. ., Kirklin, J., Evans, R., Kadko, D., Kinsohita, M., ... Rona, P. A. (1996). Conductive heat flow at the TAG active hydrothermal mound: Results from 1993-1995 submersible surveys. Geophysical Research Letters, 23(23), 3463-96. doi: 10.1029/96GL00969

Benfield, A. E. (1939). Terrestrial heat flow in Great Britain. Proceeding of the Royal Society London Serie A, 173, 428-450. doi: 10.1098/rspa.1939.0157

Blackwell, D. D., \& Richards, M. (2004). Geothermal Map of North America (Tech. Rep.). American Assoc. Petroleum Geologist (AAPG). Retrieved from http://smu.edu/geothermal/2004namap/2004namap.htm (Map 1 sheet, scale 1:6,500,000) doi: 10.1130/dnag-csms-v6.1

Bullard, E. C. (1939). Heat flow in South Africa. Proceeding of the Royal Society London Serie A, 173, 474-502. doi: 10.1098/rspa.1939.0159

Calvès, G., Schwab, A. M., Huuse, M., Clift, P. D., \& Inam, A. (2010). Thermal regime of the northwest Indian rifted margin - comparison with predictions. Marine and Petroleum Geology, 27(5), 1133-1147. doi: 10.1016/ j.marpetgeo.2010.02.010

CCGM/CGMW. (2000). Geological map of the world at 1:25 000 000. CD Rom. Retrieved from http://ccgm.free.fr/cartes \mondel_gb.html (2nd edition)

Cermak, V., Balling, N., Della Vedova, B., Lucazeau, F., Pasquale, V., Pellis, G., .. . Verdoya, M. (1992). Heat flow density. In "a continent revealed, the European GeoTraverse”, Atlas of compiled data (p. 49-57). Cambridge University Press.

Chapman, D. S., \& Pollack, H. N. (1975). Global heat flow: a new look. Earth and Planetary Science Letters, 28, 23-32. doi: 10.1016/0012-821X(75)90069-2

Cochran, J. R., \& Buck, W. R. (2001). Near-axis subsidence rates, hydrothermal cir- 
culation, and thermal structure of mid-ocean ridge crests. Journal of Geophysical Research, 106(B9), 19233-19258. doi: 10.1029/2001JB000379

Conrad, C. P., \& Lithgow-Bertelloni, C. (2006). Influence of continental roots and asthenosphere on plate-mantle coupling. Geophysical Research Letters, 33(5). doi: 10.1029/2005GL025621

Davaille, A., \& Jaupart, C. (1994). Onset of thermal convection in fluids with temperature-dependent viscosity: Application to the oceanic mantle. Journal of Geophysical Research: Solid Earth, 99(B10), 19853-19866. Retrieved from http://dx.doi.org/10.1029/94JB01405 doi: 10.1029/94JB01405

Davies, J. H. (2013). Global map of solid Earth surface heat flow. Geochemistry Geophysics Geosystems, 14(10), 4608-4622. doi: 10.1002/ggge.20271

Davies, J. H., \& Davies, D. R. (2010). Earth's surface heat flux. Solid Earth, 1, 524. doi: 10.5194/sed-1-1-2009

Davis, E. E., Chapman, N. R., Mottl, M. J., Bentkowski, W. J., Dadey, K., Forster, C. B., ... Whiticar, M. (1992). Flankflux: an experiment to study the nature of hydrothermal circulation in young oceanic crust. Canadian Journal of Earth Sciences, 29(5), 925-952. doi: 10.1139/e92-078

Davis, E. E., \& Lister, C. R. B. (1974). Fundamentals of ridge crest topography. Earth and Planetary Science Letters, 21, 405-413. doi: 10.1016/0012-821X(74) 90180-0

Davis, E. E., Villinger, H., MacDonald, R. D., Meldrum, R. D., \& Grigel, J. (1997). A robust rapid-response probe for measuring Bottom-Hole Temperatures in deep-ocean boreholes. Marine Geophysical Research, 19(3), 267-281. doi: 10.1023/A:1004292930361

Detrick, R. S., \& Crough, S. T. $\quad$ (1978). $\quad$ Island subsidence, hot spots, and lithospheric thinning. J. Geophys. Res., 83(B3), 1236. Retrieved from http://dx .doi.org/10.1029/JB083iB03p01236 doi: 10.1029/JB083iB03p01236

Divins, D. L. (2003). Total sediment thickness of the world's oceans and marginal seas. NOAA National Geophysical Data Center, Boulder, CO.

Doin, M. P., \& Fleitout, L. (1996). Thermal evolution of the oceanic lithosphere : an alternative view. Earth and Planetary Science Letters, 142, 121-136. doi: 10 $.1016 / 0012-821 X(96) 00082-9$

Fisher, A. T. (1998). Permeability within basaltic oceanic crust. Review of Geo- 
physics, 36(2), 143-182. doi: 10.1029/97RG02916

Fisher, A. T., Davis, E. E., Hutnak, M., Spiess, F. N., Zuhlsdorff, L., Cherkaoui, A., .. Becker, K. (2003). Hydrothermal recharge and discharge across 50 km guided by seamounts on a young ridge flank. Nature, 421(6923), 618-621. doi: $10.1038 /$ nature 01352

Fisher, A. T., Stein, C. S., Harris, R. N., Wang, K. L., Silver, E. A., Pfender, M., ... Villinger, H. (2003). Abrupt thermal transition reveals hydrothermal boundary and role of seamounts within the Cocos Plate. Geophysical Research Letters, 30(11), 1550-10. doi: 10.1029/2002GL016766

Fisher, A. T., \& Von Herzen, R. P. (2005). Models of hydrothermal circulation within 106 Ma seafloor: Constraints on the vigor of fluid circulation and crustal properties, below the Madeira Abyssal Plain. Geochemistry Geophysics Geosystems, 6(11), -. doi: 10.1029/2005GC001013

Fisher, A. T., \& Wheat, C. G. (2010). Seamounts as conduits for massive fluid, heat, and solute fluxes on ridge flanks. Oceanography, 23. doi: 10.5670/oceanog.2010 .63

Fourier, J. (1827). Mémoire sur la température du globe terrestre et des espaces planétaires. Mémoires de l'Académie des sciences de l'Institut de France, 569604.

Fuchs, S., \& Förster, A. (2013). Well-log based prediction of thermal conductivity of sedimentary successions: a case study from the North German Basin. Geophysical Journal International. doi: 10.1093/gji/ggt382

Goutorbe, B. (2010). Combining seismically derived temperature with heat flow and bathymetry to constrain the thermal structure of oceanic lithosphere. Earth and Planetary Science Letters, 295(3-4), -. doi: 10.1016/j.epsl.2010.04.013

Goutorbe, B., \& Hillier, J. K. (2013). An integration to optimally constrain the thermal structure of oceanic lithosphere. Journal of Geophysical Research, 118(1), 432-446. doi: 10.1029/2012JB009527

Goutorbe, B., Lucazeau, F., \& Bonneville, A. (2006). Using neural networks to predict thermal conductivity from geophysical well logs. Geophysical Journal International, 166(1), 115-125. doi: 10.1111/j.1365-246X.2006.02924.x

Goutorbe, B., Lucazeau, F., \& Bonneville, A. (2007). Comparison of several BHT correction methods: a case study on an Australian data set. Geophysical Jour- 
nal International, 170(2), 913-922. doi: 10.1111/j.1365-246X.2007.03403.x

Goutorbe, B., Poort, J., Lucazeau, F., \& Raillard, S. (2011). Global heat flow trends resolved from multiple geological and geophysical proxies. Geophysical Journal International, 187(3), 1405-1419. doi: 10.1111/j.1365-246X.2011.05228.x

Grose, C. J., \& Afonso, J. C. (2013). Comprehensive plate models for the thermal evolution of oceanic lithosphere. Geochemistry, Geophysics, Geosystems, 14(9), 3751-3778. doi: 10.1002/ggge.20232

Hamza, V. M., \& Verma, R. (1969). The relationship of heat flow with age of basement rocks. Bulletin of Volcanology, 33(1), 123-152. doi: 10.1007/ $\mathrm{BF} 02596713$

Hardebol, N. J., Pysklywec, R. N., \& Stephenson, R. (2012). Small-scale convection at a continental back-arc to craton transition: Application to the southern Canadian Cordillera. Journal of Geophysical Research, 117(B1), B01408. doi: 10.1029/2011JB008431

Hartmann, A., Rath, V., \& Clauser, C. (2005). Thermal conductivity from core and well log data. International Journal of Rock Mechanics \&3 Mining Sciences, 42, 1042-1055. doi: 10.1016/j.ijrmms.2005.05.015

Hasterok, D. (2013). A heat flow based cooling model for tectonic plates. Earth and Planetary Science Letters, 361(0), 34-43. doi: 10.1016/j.epsl.2012.10.036

Hasterok, D., \& Chapman, D. S. (2008). Global heat flow: A new database and a new approach. AGU Fall Meeting Abstracts.

Hasterok, D., Chapman, D. S., \& Davis, E. E. (2011). Oceanic heat flow: Implications for global heat loss. Earth and Planetary Science Letters, 311(3-4), 386395. doi: 10.1016/j.epsl.2011.09.044

Hillier, J. K., \& Watts, A. B. (2005). Relationship between depth and age in the North Pacific Ocean. Journal of Geophysical Research, 110(B02405), 10. doi: 10.1029/2004JB003406

Hofmeister, A. M. (1999). Mantle values of thermal conductivity and the geotherm from phonon lifetimes. Science, 283, 1699-1706. doi: 10.1126/science.283.5408 .1699

Hu, S.-B., He, L. J., \& Wang, J. Y. (2001). Compilation of heat flow data in the China continental area (3rd edition). Chinese Journal of Geophysics-Chinese Edition, 44(5), 611-626. doi: 10.1002/cjg2.180 
Hurtig, E., Cermak, V., Haenel, R., \& Zui, V. (1991). Geothermal Atlas of Europe. Hermann Haack Geographisch-kartographische Anstalt (RDA).

Hyndman, R. D., Davis, E. E., \& Wright, J. A. (1979). The measurement of marine by a multipenetration telemetry geothermal probe and insitu with thermal heat digital flow acoustic conductivity. Marine Geophysical Researches, 4 , 181-205.

Hyndman, R. D., Foucher, J. P., Yamano, M., Fisher, A., Berner, U., Bruckmann, W., ... Zhang, J. (1992). Deep sea bottom-simulating-reflectors: calibration of the base of the hydrate stability field as used for heat flow estimates. $\quad$ Earth and Planetary Science Letters, 109(3-4), 289-301. doi: $10.1016 / 0012-821 x(92) 90093-b$

Jaupart, C., Labrosse, S., Lucazeau, F., \& Mareschal, J.-C. (2015). Temperatures, Heat, and Energy in the Mantle of the Earth. In G. Schubert (Ed.), Treatise on geophysics (second edition) (Second Edition ed., p. 223-270). Oxford: Elsevier. doi: 10.1016/B978-0-444-53802-4.00126-3

Jaupart, C., Mareschal, J.-C., Bouquerel, H., \& Phaneuf, C. (2014). The building and stabilization of an Archean craton in the Superior Province, Canada, from a heat flow perspective. Journal of Geophysical Research: Solid Earth, 119(12), 9130-9155. doi: 10.1002/2014JB011018

Jessop, A. M., Hobart, M. A., \& Sclater, J. G. (1976). The world heat flow data collection (Vol. 5). Ottawa, Canada: Energy, Mines and Resources, Earth Physics Branch.

Jiang, G., Gao, P., Rao, S., Zhang, L.-Y., Tang, X.-Y., Huang, F., \& Zhao, P. (2016). Compilation of heat flow data in the continental area of China (4th edition). Chinese Journal of Geophysics - Chinese Edition, 2892-2910. doi: $10.6038 / \operatorname{cjg} 20160815$

Jiang, G., Hu, S., Shi, Y., Zhang, C., Wang, Z., \& Hu, D. (2019). Terrestrial heat flow of continental China: Updated dataset and tectonic implications. Tectonophysics, 753, 36-48. doi: 10.1016/j.tecto.2019.01.006

Johansson, L., Zahirovic, S., \& Müller, R. D. (2018). The interplay between the eruption and weathering of large igneous provinces and the deep-time carbon cycle. Geophysical Research Letters, 45(11), 5380-5389. doi: $10.1029 / 2017 \mathrm{~g} 1076691$ 
Johnson, H. P., Becker, K., \& von Herzen, R. P. (1993). Near-axis heat flow measurements on the Northern Juan de Fuca Ridge - implications for fluid circulation in oceanic-crust. Geophysical Research Letters, 20(17), 1875-1878. doi: 10.1029/93GL00734

Johnson, H. P., Tivey, M. A., Bjorklund, T. A., \& Salmi, M. S. (2010). Hydrothermal circulation within the Endeavour Segment, Juan de Fuca Ridge. Geochemistry Geophysics Geosystems, 11(5), Q05002-. doi: 10.1029/2009GC002957

Johnson, P., \& Hutnak, M. (1997). Conductive heat loss in recent eruptions at midoceans ridges. Geophysical Research Letters, 24, 3089-3092. doi: 10.1029/ 97GL02998

Kaul, N., Rosenberger, A., \& Villinger, H. (2000). Comparison of measured and BSR-derived heat flow values, Makran accretionary prism, Pakistan. Marine Geology, 164(1-2), 37-51. doi: 10.1016/S0025-3227(99)00125-5

Kautz, S. (2017). Global 30 Arc-Second Elevation (GTOPO30). U.S. Geological Survey. doi: 10.5066/F7DF6PQS

King, S. D., \& Anderson, D. L. (1998). Edge-driven convection. Earth and Planetary Science Letters, 160, 289-296.

Korenaga, J. (2007). Effective thermal expansivity of maxwellian oceanic lithosphere. Earth and Planetary Science Letters, 257, 343-349. doi: 10.1016/j.epsl .2007 .03 .010

Laske, G., Masters., G., Ma, Z., \& Pasyanos, M. (2013). Update on crust1.0 - a 1degree global model of earth's crust. In Geophysical research abstracts (Vol. 15, p. 2658,$)$. EGU.

Le Douaran, S., \& Parsons, B. (1982). A note on the correction of ocean floor depths for sediment loading. Journal of Geophysical Research: Solid Earth, 87(B6), 4715-4722. doi: 10.1029/JB087iB06p04715

Le Gal, V., Lucazeau, F., Cannat, M., Poort, J., Monnin, C., Battani, A., ... Hipólito, A. (2018). Heat flow, morphology, pore fluids and hydrothermal circulation in a typical Mid-Atlantic Ridge flank near Oceanographer Fracture Zone. Earth and Planetary Science Letters, 482, 423 - $433 . \quad$ Retrieved from https://www.sciencedirect.com/science/article/pii/ S0012821X17306714 doi: 10.1016/j.epsl.2017.11.035

Lee, W. H. K. (1965). The present state of heat flow observations. In IAV Interna- 
tional Symposium on Volcanology (New Zealand) (p. 313-325).

Li, C.-F., Lu, Y., \& Wang, J. (2017). A global reference model of curie-point depths based on EMAG2. Scientific Reports, 7(1). doi: 10.1038/srep45129

Liefferinge, B. V., \& Pattyn, F. (2013). Using ice-flow models to evaluate potential sites of million year-old ice in Antarctica. Climate of the Past, 9(5), 23352345. doi: $10.5194 / \mathrm{cp}-9-2335-2013$

Lister, C. R. B. (1972). On the thermal balance of a mid-ocean ridge. Geophysical Journal of the Royal Astronomy Society, 26, 515-535. doi: 10.1111/j.1365 -246X.1972.tb05766.x

Lucazeau, F., Bonneville, A., Escartìn, J., Von Herzen, R. P., Gouze, P., Carton, H., ... Adam, C. (2006). Heat-flow variations on a slowly accreting ridge: constraints on the hydrothermal and conductive cooling for the Lucky Strike segment (Mid Atlantic Ridge, $\left.37^{\circ} \mathrm{N}\right) . \quad$ Geochemistry Geophysics Geosystems, 7(7), Q07011. doi: 10.1029/2005GC001178

Lucazeau, F., Brigaud, F., \& Bouroullec, J. L. (2004). High resolution Heat Flow Density in lower Congo basin from probe measurements, oil exploration data and BSR. Geochemistry Geophysics Geosystems, 5(Q03001), 1-24. doi: 10.1029/2003GC000644

Lucazeau, F., Leroy, S., Bonneville, A., Goutorbe, B., Rolandone, F., d'Acremont, E., ... Al-Toubi, K. (2008). Persistent thermal activity at the Eastern Gulf of Aden after continental break-up. Nature Geoscience, 1(12), 854-858. doi: $10.1038 /$ ngeo359

Lucazeau, F., \& Poort, J. (2015). Global analysis of heat flow data in 2015. In 26th iugg, prague (Vol. S13 Terrestrial Heat Flow).

Mareschal, J. C., \& Jaupart, C. (2004). Variations of surface heat flow and lithospheric thermal structure beneath the North American craton. Earth and Planetary Science Letters, 223(1-2), 65-77. doi: 10.1016/j.epsl.2004.04.002

McKenzie, D., Jackson, J., \& Priestley, K. (2005). Thermal structure of oceanic and continental lithosphere. $\quad$ Earth and Planetary Science Letters, 233, 337-349. doi: $10.1016 /$ j.epsl.2005.02.005

Menard, H. W., \& McNutt, M. (1982). Evidence for and consequences of thermal rejuvenation. Journal of Geophysical Research, 87(B10), 8570. doi: 10.1029/ JB087iB10p08570 
Morin, R. H., Williams, T., Henrys, S. A., Magens, D., Niessen, F., \& Hansaraj, D. (2010). Heat flow and hydrologic characteristics at the AND-1B borehole, ANDRILL McMurdo Ice Shelf Project, Antarctica. Geosphere, 6(4), 370-378. doi: 10.1130/GES00512.1

Moucha, R., Forte, A. M., Mitrovica, J. X., Rowley, D. B., Quéré, S., Simmons, N. A., \& Grand, S. P. (2008). Dynamic topography and long-term sea-level variations: There is no such thing as a stable continental platform. Earth and Planetary Science Letters, 271, 101-108. doi: 1016/j.epsl.2008.03.056

Müller, R. D., Sdrolias, M., Gaina, C., \& Roest, W. R. (2008, April). Age, spreading rates, and spreading asymmetry of the world's ocean crust. Geochemistry Geophysics Geosystems, 9(4), Q04006. doi: 10.1029/2007GC001743

Nagao, T., Saki, T., \& Joshima, M. (2002). Heat flow measurements around the Antarctica - Contribution of R/V Hakurei. Proceedings of the Japan Academy Series B - Physical and Biological Sciences, 78(2), 19-23.

Nagihara, S., Lister, C. R. B., \& Sclater, J. G. ～(1996). $\quad$ Reheating of old oceanic lithosphere: Deductions from observations. Earth and Planetary Science Letters, 139(1-2), 91-104. doi: 10.1016/0012-821X(96)00010-6

Neumann, N., Sandiford, M., \& Foden, J. ～(2000). Regional geochemistry and continental heat flow: Implications for the origin of the South Australian heat flow anomaly. Earth and Planetary Science Letters, 183, 107-120. doi: $10.1016 / \mathrm{s} 0012-821 \mathrm{x}(00) 00268-5$

Parsons, B., \& Sclater, J. G. (1977). An analysis of the variation of ocean floor bathymetry and heat flow with age. Journal of Geophysical Research, 82, 803827. doi: 10.1029/JB082i005p00803

Perry, H. K. C., Jaupart, C., Mareschal, J.-C., \& Bienfait, G. (2006). Crustal heat production in the Superior Province, Canadian Shield, and in North America inferred from heat flow data. Journal of Geophysical Research, 111, B04401. doi: $10.1029 / 2005 J B 003893$

Pollack, H. N., Hurter, S. J., \& Johnston, J. R. (1993). Heat loss from the earth's interior: analysis of the global data set. Review of Geophysics and Space Physics, 31, 267-280. doi: 10.1029/93RG01249

Polyak, B. G., \& Smirnov, Y. A. (1968). Relationship between terrestrial heat flow and the tectonics of continents. Geotectonics, 4, 205-213. 
Rao, R. U. M., Rao, G. V., \& Reddy, G. K. (1982, jul). Age dependence of continental heat flow-fantasy and facts. Earth and Planetary Science Letters, 59(2), 288-302. doi: 10.1016/0012-821X(82)90132-7

Revelle, R., \& Maxwell, A. E. (1952). Heat flow through the floor of the Eastern North Pacific Ocean. Nature, 170, 199-200. doi: 10.1038/170199a0

Richards, F. D., Hoggard, M. J., Cowton, L. R., \& White, N. J. (2018). Reassessing the thermal structure of oceanic lithosphere with revised global inventories of basement depths and heat flow measurements. Journal of Geophysical Research: Solid Earth, 123(10), 9136-9161. doi: 10.1029/2018JB015998

Riley, S. J., DeGloria, S. D., \& Elliot, R. (1999). A terrain ruggedness index that quantifies topographic heteroigeneity. Intermountain Journal of Sciences, 5(14), 23-27.

Rogozhina, I., Petrunin, A. G., Vaughan, A. P. M., Steinberger, B., Johnson, J. V., Kaban, M. K., ... Koulakov, I. (2016). Melting at the base of the Greenland ice sheet explained by iceland hotspot history. Nature Geoscience, 9(5), 366-369. doi: 10.1038/ngeo2689

Roy, S., \& Rao, R. U. M. (2000). Heat flow in the Indian shield. Journal of Geophysical Research, 105(B11), 25-587. doi: 10.1029/2000JB900257

Rysgaard, S., Bendtsen, J., Mortensen, J., \& Sejr, M. K. (2018, jan). High geothermal heat flux in close proximity to the Northeast Greenland Ice Stream. Scientific Reports, 8(1). doi: 10.1038/s41598-018-19244-x

Salmi, M. S., Johnson, H. P., Tivey, M. A., \& Hutnak, M. (2014). Quantitative estimate of heat flow from a mid-ocean ridge axial valley, Raven field, Juan de Fuca Ridge: observations and inferences. Journal of Geophysical Research. doi: 10.1002/2014JB011086

Sandwell, D. T., \& Smith, W. H. F. (2009). Global marine gravity from retracked Geosat and ERS-1 altimetry: Ridge segmentation versus spreading rate. Journal of Geophysical Research, 114, B01411-B01411. doi: 10.1029/2008jb006008

Schatz, J. F., \& Simmons, G. (1972). Thermal conductivity of the earth material at high temperatures. Journal of Geophysical Research, 77(35), 6966-6983. doi: 10.1029/JB077i035p06966

Sclater, J. G., \& Francheteau, J. (1970). The implication of terrestrial heat flow. ob- 
servations on current tectonic and geochemical models of the crust and upper mantle of the Earth. Geophysical Journal of the Royal Astronomy Society, 20, 509-542. doi: 10.1111/j.1365-246X.1970.tb06089.x

Sclater, J. G., Hasterok, D., Goutorbe, B., Hillier, J., \& Negrete, R. (2014). Marine heat flow. In Encyclopedia of marine geosciences (pp. 1-16). Springer Netherlands. doi: 10.1007/978-94-007-6644-0_112-1

Sclater, J. G., Jaupart, C., \& Galson, D. (1980). The heat flow through oceanic and continental crust and the heat loss of the Earth. Review of Geophysics and Space Physics, 18, 269-311.

Sclater, J. G., Parsons, B., \& Jaupart, C. (1981). Oceans and continents: Similarities and differences in the mechanisms of heat loss. Journal of Geophysical Research, 86(B12), 11535-11552,. doi: 10.1029/JB086iB12p11535

Shapiro, N. M., \& Ritzwoller, M. H. (2002). Monte-Carlo inversion for a global shear-velocity model of the crust and upper mantle. Geophysical Journal International, 151, 88-105. doi: 10.1046/j.1365-246x.2002.01742.x

Shapiro, N. M., \& Ritzwoller, M. H. (2004). Inferring surface heat flux distributions guided by a global seismic model: particular application to antarctica. Earth and Planetary Science Letters, 223(1-2), 213-224. ～doi: 10.1016/j.epsl.2004.04 .011

Spinelli, G. A., \& Harris, R. N. (2011). Effects of the legacy of axial cooling on partitioning of hydrothermal heat extraction from oceanic lithosphere. Journal of Geophysical Research, 116(B9), B09102-B09102. doi: 10.1029/2011JB008248

Stein, C. S., \& Stein, S. (1992). A model for the global variation in oceanic depth and heat flow with lithospheric age. $\quad$ Nature, 359, 123-129. doi: $10.1038 / 359123 \mathrm{a} 0$

Stein, C. S., \& Stein, S. (1994). Constraints on hydrothermal heat flux through the oceanic lithosphere from global heat flow. Journal of Geophysical Research, 99 (B2), 3081-3096. doi: 10.1029/93jb02222

Tanaka, A., Yamano, M., Yano, Y., \& Sasada, M. (2004). Geothermal Gradient and Heat Flow Data in and around Japan. CD-ROM. Geological Survey of Japan.

USGS. (1997). Geologic province and thermo-tectonic age maps. Retrieved from https://earthquake.usgs.gov/data/crust/age.html

USGS. (2000). Retrieved from https://energy.usgs.gov/0ilGas/ 
AssessmentsData/WorldPetroleumAssessment/WorldGeologicMaps . aspx

Villinger, H., Grevemeyer, I., Kaul, N., Hauschild, J., \& Pfender, M.

(2002).

Hydrothermal heat flux through aged oceanic crust: where does the heat escape? Earth and Planetary Science Letters, 202(1), 159-170. doi: 10.1016/S0012-821X(02)00759-8

Vitorello, I., Hamza, V. M., \& Pollack, H. N. (1980). Terrestrial Heat Flow in the Brazilian Highlands. Journal of Geophysical Research, 85(B7), 3778-3788. doi: 10.1029/JB085iB07p03778

Vitorello, I., \& Pollack, H. N. (1980). On the variation of continental heat flow with age and the thermal evolution of continents. Journal of Geophysical Research, 85(B2), 983-995. doi: 10.1029/JB085iB02p00983

Von Herzen, R. P. (2004). Geothermal evidence for continuing hydrothermal circulation in older (>60 m.y.) ocean crust. In Hydrogeology of the oceanic lithosphere (p. 414-447). Cambridge: Cambridge University Press.

Von Herzen, R. P., Cordery, M. J., Detrick, R. S., \& Fang, C. (1989). Heat flow and the thermal origin of hotspot swells: the Hawaiian swell revisited. Journal of Geophysical Research, 94, 13-783. doi: 10.1029/JB094iB10p13783

Wessel, P., Smith, W. H. F., Scharroo, R., Luis, J., \& Wobbe, F. (2013). Generic Mapping Tools: Improved Version Released. Eos, Transactions American Geophysical Union, 94(45), 409-410. doi: 10.1002/2013EO450001

White, N., Thompson, M., \& Barwise, T. (2003). Understanding the thermal evolution of deep-water continental margins. Nature, 426, 334-343. doi: 10.1038/ nature02133

Whittaker, J. M., Goncharov, A., Williams, S. E., Müller, R. D., \& Leitchenkov, G. (2013). Global sediment thickness data set updated for the AustralianAntarctic Southern Ocean. Geochemistry, Geophysics, Geosystems, 14(8), 3297-3305. doi: https://doi.org/10.1002/ggge.20181

Wilson, M. F. J., O’Connell, B., Brown, C., Guinan, J. C., \& Grehan, A. J. (2007). Multiscale terrain analysis of multibeam bathymetry data for habitat mapping on the continental slope. Marine Geodesy, 30(1-2), 3-35. doi: $10.1080 / 01490410701295962$

Yamano, M., Uyeda, S., Aoki, Y., \& Shipley, T. H. (1982). Estimates of heat flow derived from gas hydrates. Geology, 10, 339-343. 